\title{
COMMUNITY APARTMENTS: CONDOMINIUM OR STOCK COOPERATIVE?
}

\section{INTRODUCTION}

The steady concentration of population that has taken place in the United States since the end of World War II has occurred primarily in the peripheral low density urban areas. ${ }^{1}$ The resulting urban sprawl has led to the development of "sloppy, sleazy, slovenly, shp-shod, semi-cities" called "slurbs."2 This phenomenon is expected to continue, ${ }^{3}$ creating a need for more efficient use of land through high rise multi-family dwellings located in those areas where facilities for employment, education, recreation, and public services already exist.. ${ }^{4}$ One problem in fulfilling this need is to provide a type of residence that will attract the expanding urban population to developed urban areas.

Rental, the traditional form of tenure in multi-family dwellings, is unsatisfactory because it does not satisfy the desire for hoine-ownership ${ }^{5}$ and because it is not economically advantageous. ${ }^{6}$ To improve the attractiveness of multi-family dwellings the concept of community ownership was developed. ${ }^{7}$ The most popular form has been the stock cooperative in which a corporation holds title to the land and the building, and each tenant-shareholder owns stock in the corporation and a lease to a particular apartment in the building. ${ }^{8}$

1 Hanr, Land-Use Planning 347 (1959).

2 Wood \& Heller, California Gonkg, Going .. . 10 (1962). See also Temko, Politics, Planning and the Spreading Slurbs, San Francisco Chronicle, Jan. 15, 1962, p. 14, col. 1 ; id., Jan. 16, 1962, p.2, col. 1. For an account of the population boom that California is experiencing and the demands it creates, see Wood \& Herrer, op. cit. supra at 7-8. See also EDITORS of Fortune, The Exploding Metropolis 115-17 (1958); Futterman, The Future of OUR Cities 5-8 (1961).

3 Meier, Planning for Tomorrow's World, 1955 Plannnge 15, 16-17 (1956).

${ }^{4}$ Le Corbusier, Concernang Town Plannang 67, 68 (1948); Hennessey, Co-operative Apartments \& Town Houses, 1956 IrL. L.F. 22.

- E.g., Duhl, Planning for Tomorrow's World, 1955 Plannnge 31, 33 (1956); George, THE SATE of FLATS (2d ed. 1959); Hearings Before a Subcommittee on Various Bills to Amend the Federal Housing Law of the Senate Committee on Banking \& Currency, 86th Cong., 2d Sess. 585, 597 (1960) ; Renuarks of John G. Melville, William Mason, and David Robinson, Condominium Conference held at the Claremont Hotel, Berkeley, California on Nov. 28, 1961, sponsored by Associated Home Builders of the Greater East Bay [heremafter cited as Condominiun Conference]. But see Leach, The Sale of Flats, 1957 J. Plannnga \& Property L. 403.

6 The unavailability of land and the cost of construction deters development in densely populated areas. See, e.g., Remarks of John G. Melville, William Mason, Rollin E. Meyer, Jr., William H. Young, Condominiun Conference. The tax treatment of apartment occupants compares unfavorably with that of home owners and results in a generally higher cost of living. Thompson, The High Cost of Renting, ARCHITECTURAI F., June 1958, at 101.

7 McCullough, Co-operative Apartments in Illinois, 26 CEr.-KENT L. REv. 303 (1948); 4 Powelx, Reat Property 709 (1954); Vogex, The Co-op Apartment (1960).

8 See generally 4 Poweis, Real Property 709-14 (1954); Vogex, The Co-op Apartament (1960) ; Castle, Legal Phases of Co-operative Buildings, 2 So. Cax. L. Rev. 1 (1928); Hennessey, Co-operative Apartments \& Town Houses, 1956 IrI. L.F. 22; Isaacs, To Buy or Not to Buy: That is the Question-What is a Co-operative Apartment?, 1958 RECORD NEW YORK CITY B.A. 203; Marks \& Marks, Coercive Aspects of Housing Co-operatives, 42 IrL. L. REv. 728 (1948); McCullough, Co-operative Apartments in Illinois, 26 CHI.-KeNT L. REv. 303 (1948); Rosenfeld, The Sale of Individual Apartment Suites, 18 FAcultx OF TORONTo L. REv. 12 (1961); 
Certain legal consequences of this form make it unattractive as a vehicle for providing some of the basic advantages of "home-ownership." First, since the corporation is the legal owner of the land and building, it alone can mortgage the property and it alone is liable for the real property taxes. The lien imposed to secure either of the obligations is upon the entire real property interest. Thus, although each tenant-shareholder agrees to pay a proportionate share of the mortgage payments and real property taxes, the failure of one to pay his share results in a default that must be cured by the others if foreclosure of the lien on the whole property is to be avoided. ${ }^{9}$ In addition, each tenant-shareholder's proportionate obligation is based upon the amount and terms of financing arranged by the corporation. Cash cannot be paid beyond the down payment required, ${ }^{10}$ nor may financing be availed of which is better suited to individual needs. ${ }^{11}$

A second disadvantage is that since the tenant-shareholder is only a lessee, his property rights are restricted: He may not alienate his interest in any way except with the consent of the board of directors; ${ }^{12}$ his interest is subject to a right of entry reserved by the lessor; ${ }^{13}$ any facilities provided in addition to the apartment, such as storage space, laundry facilities, and garage, are used pursuant to a revocable license only; ${ }^{14}$ and the leasehold interest is conditional. ${ }^{15}$

The condominium was developed to provide a legal structure with more of the attributes of home ownership: ${ }^{16}$ each purchaser receives a fee simple in an apart-

Yourman, Some Legal Aspects of Co-operative Housing, 12 LAW \& ConTEMr. РRов. 126 (1947); Note, 61 HaRv. L. REv. 1407 (1948).

Another type that has been widely used is the so-called deed plan, or T.I.C. (tenancy-incommon), where each owner receives a fee to an undivided interest in the building and land with an exclusive right to occupy a particular apartment. Barber, Co-op-The Deed Plan Community Apartment Project, 36 CAL. S.B.J. 310 (1961). See also Stern, Community Ownership (1925) (unpublished J.D. thesis found in University of California Law Library, Berkeley Campus) for a description and analysis of it and other variations.

${ }^{9}$ For a discussion of the financial burdens involved and suggestions on how to guard against this risk, see Note, 61 HARv. I. REv. 1407, 1411-16 (1948).

It has been argued that the risks of this financial interdependence are largely academic since another depression (such as the depression of the 1930's, which led to many failures in stock cooperatives) is unlikely and simce the "Ioan to value" limits imposed on institutional lenders and by the Corporation Commissioner is far below that which occurred in the 1930's. Interview With Tevis Jacobs, Member of San Francisco Bar, San Francisco, Dec. 1961.

10 Buyers who wish to take clear of any imdebtedness on the property can do so only if all are willing and able to pay their proportionate cash obligation. For example, the Berkeley Town House, a stock cooperative at Dana and Parker Streets, Berkeley, California, is beimg financed in this way.

11 Usually, however, the corporation can obtain the most favorable terms, since it can use the entire real property as security. Any individual able to obtain more favorable terms can probably do so on the basis of his personal signature regardless of the collateral security. On the other hand, FHA insured financing is an advantage made possible through condominium. See discussion at Part III, B, 2(c) infra.

12 See, e.g., Voget, THE Co-op Apartment app. A, §§ 5, 6 (1960) [hereinafter cited as VoGEL]. The writers have examined numerous instruments used in connection witl stock cooperatives and have found them to be substantially identical to the provisions contained in the forms in VoGEL. All subsequent citations to VoGEx are based on the same experience.

13 VoGEr app. A, § 13.

14 VoGEL app. A, \& 15.

15 Voger app. A, \& 18.

16 Remarks of William II. Young, Condominium Conference; Young, Four Ways to Provide Middle Income Housing, Cal. Builder, Nov. 1961, at 11.

Development of condominiums in Europe, South America, New Zealand, and Australia is quite extensive. See George, The Sale of Frats (2d ed. 1959); Adams, Flats and Offices: 
ment, including a balcony, storage space, and a garage, and a deed to an undivided interest in the common areas. The fee interest in the condominium unit is generally defined to include only the interior surface walls and the air space contained therein, so that structural parts such as bearing walls, service lines, elevators and elevator shafts, and areas used by all are owned in common. The separate fee interest is made determinable upon total or partial destruction of the building and a decision by the group of owners not to rebuild. An undivided interest in the reversion is also conveyed. Finally, each fee simple interest is made subject to certain covenants, conditions, and restrictions contained in a recorded instrument, pursuant to which a manager or board is elected by the owners to enforce the restrictions.

This type of cooperative venture has received a great deal of attention recently. ${ }^{17}$ The purpose of this Comment is to examine the condominium and compare it with the stock cooperative as a means of providing home ownership in a multi-family dwelling. In particular, analysis will be concerned with (1) whether condominium is a valid legal interest; (2) to what extent the communal aspects of the condominium plan of ownership are inconsistent with true home ownership; (3) what real home ownership benefits it offers; and (4) what administrative and regulatory burdens are or may be imposed upon the developer of a condominium project. Although special attention will be given to the Califorma approach to condominium ownership, the problems raised and the solutions offered will require the same analysis in any jurisdiction.

II

\section{FEE SIMPLE OWNERSHIP OF AN APARTMENT}

In designing an instrument to convey fee simple title to an apartment, the draftsman is faced with two fundamental questions: (1) what should be the nature of the tenant-owner's interest in his individual apartment; (2) what is the most desirable way for the tenant-owners to hold those portions of the building that will be used in common?

\section{A. A Several Interest}

California, ${ }^{18}$ along with a number of other states, ${ }^{19}$ has long recognized the legality of conveying a freehold estate in a portion of a building. However, it is

Freehold or Leasehold Titles, 34 N.Z.L.J. 268 (1958) ; Coin, Oven Your Own Flat-Some Conveyancing Aspects, 35 N.Z.L.J. 295 (1959); Leyser, The Ozenership of Flats-A Comparative Study, 7 Int'x \& CoMp. L.Q. 31 (1958); Norris, Why Not Ovn-Youtr-Own Flat?, 33 Austr. L.J. 361 (1960).

17 E.g., The Wall Street Journal, Mar. 8, 1962, p. 1, col. 1; RAMSey, Condomintum: ThE NEw Look Iv Co-ops (1961); Barnes, Accelerated Growth of Condominiums Expected from New Housing Bill Law, Lawyers Title News, Aug. 1961, at 5; McIver, Condominium-A New Frontier in Housing, Cal. Builder, Nov. 1961, at 8.

18 Thompson v. McKay, 41 Cal. 221 (1871); Galland v. Jackman, 26 Cal. 79 (1864). See Jameson v. Hayward, 106 Cal. 682, 686, 39 Pac. 1078, 1079 (1895).

19 McConnel v. Kibbe, 43 Ill. 12 (1867); Anderson School Township v. Milray Lodge, 130 Ind. 108, 29 N.E. 411 (1891); Weaver v. Osborne, 154 Iowa 10, 134 N.W. 103 (1912); Temple of the Mysterious Ten v. Tabernacle, 124 S.W. 304 (Ky. 1910); Hahn v. Baker Lodge, 210 Ore. 30, 27 Pac. 166 (1891); Townes v. Cox, 162 Tenn. 624, 39 S.W.2d 749 (1931). See generally Ball, Division into Horizontal Strata of the Landscape Above the Surface, 39 YaIE L.J. 616 (1930). 
also recognized that the conveyance of a portion of a building vests in the grantee no more than a defeasible fee, which will determine upon the destruction of the building, the title at that point reverting to the owner of the underlying soil. ${ }^{20}$ Such an interest does not have the permanency or continuity of interest that an individual expects to obtain when he purchases a home.

To provide a more permanent interest, condominium deeds include detailed agreements on what is to happen upon partial or total destruction of the building. ${ }^{21}$ These agreements provide that the building will always be adequately insured and that the disposition of the proceeds-i.e., whether they will be used to rebuild or distributed pro rata-will be determined by the will of a specified majority of the tenant-owners.

There is disagreement over whether the foregoing plan solves the problem of destruction. ${ }^{22}$ Most of the attorneys working in the field feel that since the tenantowner's fee in the building will determine upon destruction, there must be some device for revesting the fee in the reconstructed umt. ${ }^{23}$ Their solution is to vest specifically in the tenant-owner a fee in the airspace enclosed by the apartment unit. ${ }^{24}$ This interest in the airspace would survive the destruction of the building. ${ }^{25}$ Upon reconstruction of the individual units within this space, title to the tangible portions of the building would vest in the owner of the airspace by accession. ${ }^{20}$

The validity of aerial subdivision has raised more concern than any other aspect of the condominium concept. ${ }^{27}$ There is no substantial reason for this concern. Under the common law it was clear that air space was owned by the individual holding title to the underlying soil. ${ }^{28}$ The principle, though somewhat restricted, is still recognized today in many state statutes ${ }^{20}$ and in the aviation trespass cases. ${ }^{30}$

20 Weaver v. Osborne, 154 Iowa 10, 134 N.W. 103 (1912); Hahn v. Baker Lodge, 210 Ore. 30, 27 Pac. 166 (1891) ; Bell, Air Rights, 23 IrL. L. Rov. 251, 257 (1928) ; Note, 165 L.T. 78 1928) ; cf. Ainsworth v. Ritt, 38 Cal. 89 (1869) (destruction of a building terminates a leasehold interest in it). Contra, GEorge, The SALE of Flats 29 (2d ed. 1959); Watts, The Conveyance of a Flat-The Question of Defeasibility, 1 AusrL. L.J. 363 (1928).

21 That such agreements will provide continuity of interest see Weaver v. Osborne, 154 Iowa 10, 134 N.W. 103 (1912).

22 Interview With Jackson Moffat, Vice-Pres., California Pacific Title Ins. Co., San Francisco, Cal., Feb. 16, 1962.

23 Panel Discussion, "How We Closed the Sale on Our First Condominium," Condominium Conference; Borgwardt, The Condomitium, 36 CAL. S.B.J. 603, 604 (1961).

24 Ibid.

25 Ball, Division into Horizontal Strata of the Landscape Above the Surface, 39 Yale L.J. 616, 619 (1930).

26 Cal. Civ. Code § 1013. See generally American Law of Property \$ 19.9 (Casner ed. 1952) [hereinafter cited as AMrerican Law of Property].

However, it should be noted that this principle is commonly stated to apply to the fixation of things to "Iand." Unless land is considered to be used in its broad sense, meaning real property, the conveyance of air space will accomplish nothing as far as revesting of title is concerned.

27 See, e.g., Remarks of Lloyd Hanford, Condominium Conference; RAMSEx, CondommIUM: THE NEW LOOK IN Co-OPS (1961).

28 The common law was (under the inaxim Cujus est solum, ejus est usque ad coeletm et ad inferos) that the owner of the soil owned to the sky and to the depths. United States $v$. Causby, 328 U.S. 256, 260 (1946) ; Ball, The Jutral Nature of Land, 23 Irc. L. REv. 45,48 (1928). For a brief discussion of the history of this maxim see Sweetland v. Curtiss Airport Corp., 41 F.2d 929 (N.D. Obio 1930).

29 See, e.g., CAL. PUB. UTI. CoDE $\S 21402$. For an excellent discussion of these statutes sce Note, 1960 IrL. L.F. 303, 310.

30 The Supreme Court of the United States has held that "The landowner owns at least as much of the space above the ground as he can occupy or use in connection with the land." 
If the air space is owned by the individual holding title to the underlying land, subdividing the sky can only be invalid if it is held that the space cannot be conveyed apart from the soil. But in a legal system that recognizes the severance of estates beneath the soil, ${ }^{31}$ there is no justification for denying the severance of estates above the soil. Furthermore, the few cases deahing with the problem have upheld conveyances of air space apart from the soil ${ }^{32}$ and it is now accepted in the business commumity that such conveyances are valid..$^{33}$

Aside from validity, the conveyance of air space presents complications for the draftsman. First, the tangible portions of the building cannot be expected to remain in the same place indefinitely. Shifting of the earth and settling of the building will ultimately cause one unit to encroach upon the airspace of another. This problem is solved, however, by providing reciprocal easements of encroachment in the deeds.

Second, upon destruction of the building the sky would remain subdivided into separately owned cubes. If the apartment building were not rebuilt the owners could quitclaim their respective interests for reasonable value so that the land would be marketable. But it is not difficult to imagine one misanthrope holding out for an exorbitant price. Furthermore, any irregularities in the reconveyance could cause chaos. To obviate these problems many attorneys suggest that the airspace be conveyed as a fee simple determinable instead of a fee simple absolute. ${ }^{34}$ The fee determmes if the building is destroyed and the tenantwowners do not elect within a specific time to rebuild under the reconstruction covenants. At that point the reverter clause vests title to the airspace in the tenant-owners as tenants in common. ${ }^{35}$

If an air space conveyance is to effectively provide continuity of interest, the reconstructed apartment must fit within the original cube of space. Aside from the

United States v. Causby, 328 U.S. 256, 264 (1946). The fact that airspace can be owned is also borne out by suits by owners of land adjoining airports involving low flying aircraft. See, e.g., Ackerman v. Port of Seattle, 55 Wash. 2d 400, 348 P.2d 664, 77 A.L.R.2d 1344 (1960); Scott v. Dudley, 214 Ga. 565, 105 S.E.2d 752 (1958). Cases involving aviation easements such as United States v. 48.10 Acres of Land, 144 F.Supp. 258 (S.D.N.Y. 1956), also support the conclusion that space can be owned.

31 Kidwell v. General Petroleunı Corp., 212 Cal. 720, 300 Pac. 1 (1931) (recognizes the possibility of leasing oil and gas rights to a certain depth, but no further); Graciosa Oil Co. v. Santa Barbara County, 155 Cal. 140, 99 Pac. 483 (1909); Zaskey v. Farrow, 159 Kans. 347, 154 P.2d 1013 (1945); Bittner v. Quemahoning Coal Co., 271 Pa. 579, 116 Atl. 42 (1922).

32 Pearson v. Matheson, 102 S.C. 377, 86 S.E. 1063 (1915) ; Taft v. Washington Mut. Sav. Bank, 127 Wash. 503, 221 Pac. 604 (1923). Accord, R.M. Cobban Realty Co. v. Donlan, 5 Mont. 58, 149 Pac. 484 (1915) ; Piper v. Taylor, 48 N.D. 967, 968, 188 N.W. 171, 172 (1922).

33 Becker, Subdividing the Air, 1931 CHI.-KENT L. REv. 40; Wall Street Journal, March 21, 1962, p.1, col. 8 .

${ }^{34}$ See note 23 supra.

35 There is one possible flaw in this plan. Since the same person will hold the determinable fee and the right of reverter, it is feared that the doctrime of merger of title will apply. See 1 AMIrRican LAw of Property $\$ 4.60$. This would eliminate the safety feature provided by separate interests. Panel Discussion, "How We Closed the Sale of Our First Condominium," Condominium Conference.

This fear is unfounded since "equity will prevent or permit a merger, as will best subserve the purposes of justice, .... If the interest of the person in whoin the several estates have united, as shown from all the circumstances, will be best subserved by keeping them separate, the intent so to do will ordinarily be iniplied." Jameson v. Hayward, 106 Cal. 682, 688, 39 Pac. 1078,1080 (1895). 
physical problems ${ }^{36}$ of achieving such a feat, it may be undesirable for the tenantowners to be restricted to the original plan of construction.

These complications have led some condominium experts to believe that the conveyance of air space creates more problems than it solves. ${ }^{37}$ An alternative solution would be a covenant requiring the owners of the underlying soil (in this case, the tenant-owners as tenants in common) to execute new deeds to the proper tenant-owners once the building has been rebuilt. Yet this solution is not without drawbacks. It might be difficult to make such a covenant run with the land, and as a vehicle for the future vesting of an interest in real property it would have to be limited to the perpetuities period. Nevertheless, it is superior to the conveyance of air space; besides eliminating the necessity for the use of encroachment easements and defeasible fees, this solution, unlike the airspace method, would facilitate rebuilding to new specifications.

\section{B. A Community Interest}

Although complete several ownership of the building is theoretically possible, ${ }^{88}$ it is not practical for two reasons: (1) in a large modern apartment house there are many facilities such as elevators, gardens, and swimming pools which do not lend themselves to several ownership; (2) common rights and duties would have to be completely defined through the use of cumbersome easements and covenants. ${ }^{30}$

Therefore some form of common ownership is appropriate for the areas used by all. One alternative is to form a non-profit corporation to hold these areas for the benefit of the tenant-owners. This, however, would result in a legal entity similar to a stock cooperative rather than a condominium. Instead, in the condominium plan the tenant-owners hold the common parts in co-tenancy. Rights of ingress and egress are thus guaranteed by the nature of the interest. ${ }^{40}$ Further, problems of support and repair are alleviated since any co-tenant has the right to enter upon and repair the common parts.

\section{III}

THE PURCHASER'S CONSIDERATIONS

\section{A. The Communal Aspects}

Although a condominium attempts to provide rights similar to individual home ownership, by its nature it involves a communal environment; it therefore requires that each tenant-owner yield some individual rights for the sake of achieving a

${ }^{38}$ This problem may be solved through a unique method of description. The monuments describing the units may be made an integral part of the building; if the building is destroyed there is merely the problem of re-establishing a destroyed monument. Letter from John $P$. Borgwardt to California Law Review, April 30, 1962.

87 See note 22 supra.

38 In Scotland it is quite common to find an apartment house with the first floor tenant owning his unit and the land, the top floor tenant owning his unit and the roof, while the tenants in the middle units own merely a shice of the building. Dickson, Freehold Tille to Flats, 28 L. INST. J. 133 (1954).

30 Moffat, Condominium: Title Insurance, Cal. Builder, June 1961, at 16.

40 This result will endure only for so long as the common parts remain attached to the several interest. For problems arising upon severance of the common parts from the several interest see discussion at III, A, I infra. 
harmonious cooperative venture. ${ }^{41}$ To secure this goal, covenants, conditions, and restrictions are contained in a recorded declaration incorporated by reference in each deed. ${ }^{42}$ The condominium declaration should include provisions to meet three basic problems: (1) preservation of the legal entity; (2) provision for management; and ( 3 ) preservation of a harmonious environment.

\section{Preservation of the Legal Entity}

As has been pointed out, condominium draftsmen purposely provide for coownership of common areas and facilities. This gives each tenant-owner the necessary rights of access and maintenance without cumbersome supplemental arrangements. But a problem arises in that each co-tenant also has as an incident to his interest the right to alienate, ${ }^{43}$ and this includes the right to compel partition of the common parts through judicial process. ${ }^{44}$ This could lead to physical partition of the property, each co-tenant receiving a several interest in proportion to the amount of his undivided interest, or to a decree of sale with direction to divide the proceeds. ${ }^{45}$ Fear that the necessary rights concommitant to a tenancy in common will be lost if partition results has prompted draftsmen to include a provision waiving the right to partition. ${ }^{46}$

This fear is unfounded in the case of physical partition. The California Civil Code expressly provides that in the case of a transfer of real property necessary easements of access ${ }^{47}$ arise by operation of law. ${ }^{48}$ Pursuant to this statute, ease-

41 Cf. Note, 51 HaRv. I. REv. 320 (1937) (need for and content of covenants, conditions, and restrictions in subdivisions is expanding). See, e.g., In re Bangle, 54 Cal. App. 415, 201 Pac. 968 (1921).

42 See, e.g., Grant Deed of Palo Alto Estates, 518-528 Everett Avenue, Palo Alto, California [hereinafter referred to as Palo Alto Estates].

43 Payne v. Callahan, 37 Cal. 2d 503, 99 P.2d 1050 (1940) ; La Laguna Ranch Co. v. Dodge, 18 Cal.2d 132, 114 P.2d 351 (1941); see generally 2 AMrerican LAw of Property $§ 6.10$.

44 Cal. Code Civ. Proc. $\$ 752$; see, e.g., De Roulet v. Mitchel, 70 Cal. App. 2d 120, 160 P.2d 574 (1945); cf. Akley v. Bassett, 189 Cal. 625, 209 Pac. 576 (1922); see generally 2 AMrerICAN LAW OF PROPERTY \$ 6.21.

45 CAL. CODE CIV. Proc. \$\$ 752, 763, 764 provide that the court has discretion to order physical division or a partition sale.

46 This problem does not exist where the community apartment is organized under the stock cooperative method. There, the corporation alone, as owner-lessor of the land and building, has the duty to provide the services and maintain the building, and the right to sell the land and building, usually as a whole. The tenant-sharcholders as lessees bave those rights necessary to the enjoyment of their leasehold. Partition is simply not permitted under sueh an arrangement.

47 The typical easements involve rights of ingress, egress, and ways of necessity. E.g., Fristoe v. Drapeau, 35 Cal. 2d 5, 215 P.2d 729 (1950); Vargas v. Maderos, 191 Cal. 1, 214 Pac. 58 (1923); Rubio Cañon Land \& Water Ass'n v. Everett, 154 Cal. 29, 96 Pac. 811 (1908); Zeller v. Browne, 143 Cal. App. 2d 191, 299 P.2d 315 (1956). Rights of drainage and sewage and to other accessory pipe lines, which could therefore include easements to use the water, gas, and electric lines running through the common areas of the building, have also arisen. Jersey Farm Co. v. Atlantic Realty Co., 164 Cal. 412, 129 Pac. 593 (1912) ; Jones v. Sanders, 138 Cal. 405, 71 Pac. 506 (1903); Palvutzian v. Terkanian, 47 Cal. App. 47, 190 Pac. 503 (1920). See also Laux v. Freed, 53 Cal.2d 512, 348 P.2d 873 (1960) (Cal. Civ. Code $\$ 1104$ is not limited by the enumeration of easements in Cal. Civ. Code $\$ 801)$.

48 CAL. Crv. Code $\$ 1104$ provides:

A transfer of real property passes all easements attached thereto, and creates in favor thereof an easement to use other real property of the person whose estate is transferred in the same manner and to the same extent as such property was obviously and permanently used by the person whose estate is transferred, for the benefit thereof, at the time when the transfer was agreed upon or completed. 
ments by implication can arise upon the severance of the dominant and the servient estates where the separation results from a partition between co-tenants. ${ }^{40}$ The prerequisites for the creation of easements by implication-apparent and continuous previous use $\mathrm{e}^{50}$ and reasonable necessity $\mathrm{y}^{51}$ - should be satisfied in the case of physical partition of the common parts of a condominium development. Since the owner of an easement upon the land of another has the right to enter in order to maintain the easement, ${ }^{52}$ it is evident that physical partition would leave the tenant-owners in the same practical relationship as before..$^{53}$

There is still reason to fear a partition action, however, since it would more likely result in a decree of sale, ${ }^{54}$ the consequences of which would be serious. The apartment owners would be without any access at all except on some negotiated basis with the purchaser-owner of the common areas. ${ }^{55}$ The argument that the common areas are unmarketable would not deter the malicious owner from suing for partition and purchasing at the sale, however low the market value.

It is to prevent the destructive effect that a partition sale might have upon the legal structure of a condominium that a restraint on the right to partition is and should be imposed in the condomimium declaration. The majority rule recognizes

49 Mesmer v. Uharriet, 174 Cal. 110, 162 Pac. 104 (1916) (dictum); Blum v. Weston, 102 Cal. 362, 36 Pac. 778 (1894). See also Southern Pac. Co. v. L.A. Milling Co., 177 Cal. 395, 170 Pac. 829 (1918) ; Cheda v. Bodkin, 173 Cal. 7, 158 Pac. 1025 (1916); Jersey Farm Co. v. Atlanta Realty Co., 164 Cal. 412, 129 Pac. 593 (1912). Cf. 2 Amrerican Law of Property \$ 8.37.

50 See, e.g., Southern Pac. Co. v. Milling Co., supra note 49; Warfield v. Basich, $161 \mathrm{Cal}$. App. 2d 493, 326 P.2d 725 (1958); Rosebrook v. Utz, 45 Cal. App. 2d 726, 114 P.2d 715 (1941); see generally 2 AMrerican LAW of Property \$\$ 8.40-.42.

51 See, e.g., Jordan v. Henck, 166 Cal. App. 2d 321, 333 P.2d 117 (1958); Warfield v. Basich, supra note 50; Zeller v. Browne, 143 Cal. App. 2d 191, 299 P.2d 315 (1956); see generally 2 Amerscan Law of Property \$ 8.43.

62 Durfee v. Garvey, 78 Cal. 546, 21 Pac. 302 (1889) ; Pico v. Cohmas, 32 Cal. 578 (1867).

53 Most condominium deeds expressly reserve non-exclusive appurtenant easements of ingress, egress, and support through the commonly used portions of the building as a benefit to and burden of each unit owner. E.g., Grant Deed of Palo Alto Estates. Because there is unity of ownership of the easement and dominant tenement to which it is appurtenant and of the servient tenement, a merger results, thus extinguishing the easements. Cheda v. Bodkin, 173 Cal. 7, 158 Pac. 1025 (1916); CaL. Crv. Code $\$ 811(1)$. See generally 2 AMrerrcan Law of Property \$\$ 8.88-.90.

It is arguable that the general rule is inapplicable where, as here, the easement and the dominant tenement is owned in severalty and the servient tenement in common, or where the easement or domimant tenement is held under a determinable fee while the servient estate is held in fee simple absolute. If either of these grounds is sufficient to make the estates unequal, suspension and revival rather than extinction should result. See GaLE, EASEMENTs 306-09 (1959); see also Cheda v. Bodkin, supra; Rogers v. Flick, 144 Ky. 844, 139 S.W. 1098 (1911); Dority v. Dunning, 78 Me. 381,6 Atl. 6 (1886).

But even if either argument fails, the specific reservation should still be included in the condominium deed because it does provide another manifestation of intent to create the necessary easements. See 2 AMERICAN LAw of Property \$ 8.33. It may also serve to render the common parts valueless and therefore unmarketable. See text following note 55 infra.

54 Although such things as stairwells, elevator shafts, power service lines, and the like may theoretically be physically apportioned into several interests (see note 38 silpra), the impracticability of doing so and the possibility of prejudice to the respective cotenants would probably compel the court to order a partition sale. See note 45 supra.

55 In Hawaiian land transactions, for instance, the developer leases the land, constructs the project, and subleases to each purchaser an apportioned interest of the entire lease; each purchaser pays a proportionate value of the leasehold interest and assumes a proportionate amount of the lease obligation. Interviews With Members of the Hawaiian Bar, Honolulu, Hawaii, Dec. 1961. 
that co-tenants may by contract waive the right to judicial partition. ${ }^{56}$ Since the power to convey the undivided interest is not thereby restrained, the rule against restraints on alienation is not violated. ${ }^{57}$ However, if the restriction is perpetual in time it is void; it must not extend beyond a reasonable time. ${ }^{58}$ What constitutes a reasonable time is not settled. In most cases upholding the restriction, the waiver did not last beyond the period of the rule against perpetuities. ${ }^{59}$ In a condominium the declaration usually provides that there shall be no partition until there is total or partial destruction of the building without a decision to repair or rebuild. ${ }^{60}$ The duration of this restriction is not limited by the period of the rule against perpetuities. Though a court might be persuaded to recognize the reasonableness of the restriction ${ }^{61}$ it would be advisable to avoid the problem by a provision limiting the applicability of the clause agamst partition to the stated condition or to a life or lives in being plus twenty-one years, whichever is shorter. ${ }^{62}$

Even though the right to compel partition may be limited, some fear has been expressed that a grantee of an undivided interest would not be so restricted. ${ }^{63} \mathrm{~A}$ separate conveyance of the common interest should not, however, result in unde-

56 Teutenberg v. Schiller, 138 Cal. App. 2d 18, 291 P.2d 53 (1955); Rowland v. Clark, 91 Cal.App. 2d 880, 206 P.2d 59 (1949); Miranda v. Miranda, 81 Cal. App. 2d 61, 183 P.2d 61 (1947); De Harlan v. Harlan, 74 Cal. App. 2d 555, 168 P.2d 985 (1946) ; Asels v. Asels, 43 Cal. App. 574, 185 Pac. 419 (1919). See generally 6 AMrerican LAW oF Property \$§ 26.72-.73.

57 See 2 Amertcan LaW of Property $\$ 6.26$.

58 E.g., Saulsberry v. Saulsberry, 290 Ky. 132, 160 S.W.2d 654 (1942); Roberts v. Jones, 307 Mass. 504, 30 N.E.2d 392 (1940) ; Haeussler v. Missouri Iron Co., 110 Mo. 188, 19 S.W. 75 (1892); Freencan, Cotenancy \& Partition $\$ 442$ (1874). Contra, Hunt v. Wright, 47 N.H. 396 (1867).

506 Adrertcan Law of Property \$ 26.74. See also Stames \& Sactin, The Law of Future INTERESTS \$1141 (2d ed. 1956) [hereinafter cited as SIMrEs \& SMrTH].

60 E.g., $\$ 2$ of Declaration of Covenants, Conditions, and Restrictions, Palo Alto Estates.

61 The purpose of measuring the period of the restriction in terms of the destruction of the building is to insure the preservation of the condominium legal structure inherent in cotenancy as long as the need exists. When the building is destroyed and no decision to rebuild is made, there is no longer any reason to protect against partition, and the right of partition may then be pursued. Remarks of Jess Long, Condominium Conference.

Authority does exist for upholding restraints upon partition that are reasonable in purpose without regard for the mechanical test of the rule against perpetuities. Martin v. Martin, 170 III. 639, 48 N.E. 924 (1897); Avery v. Payne, 12 Mich. 549 (1864); Hunt v. Meeker County Abstract \& Loan Co., 128 Minn. 207, 150 N.W. 798 (1915) (dictum); Baldwin v. Humphrey, 44 N.Y. 609 (1871); Coleman v. Coleman, 19 Pa. St. 100 (1852). See also Hunt v. Wrigbt, 47 N.H. 396 (1867). Two states have enacted statutes validating just such a restriction. ARR. Star. ANN. $\$ 50.1007$ (Supp. 1961); Horizontal Property Act, Act. No. 180 (Hawaii, July 10, 1961).

62 Where a perpetuities clause is used, care should be taken to comply with the rule that the measuring life or lives not be so numerous that it is impossible to ascertain the date of their demise. Grax, The RuIe Agarnst Perperuiries 217 (4th ed. 1942). The living descendants of John F. Kennedy or of Queen Elizabeth $H$ are the measuring lives used in some instruments. Both are clearly within the rule.

63 RaArsey, Condonmmion: THE NEw LOOK In Co-ops 27 (1961). See also FHA Reg. $\$ 234.65,26$ Fed. Reg. 7500 (1961), which requires that the several and the undivided interests be inseparable.

The severability of the interest in the unit and the interest in the common parts could raise a problem in testamentary disposition. A specific devise of the fee interest to "apartment number 8 " to one person, with a general residuary devise to another could result in the two interests going to different persons. Letter from John P. Borgwardt to California Law Revieze, April 30,1962 . Tbis problem can be prevented only if the estate planner is familiar with the nature of the condominiun interests and makes the owner's intent clear. 
sirable consequences. The grantee would take his interest as a tenant in common ${ }^{84}$ and should therefore be bound by the restrictions contained in the condominium declaration, ${ }^{65}$ including the restriction on the right to partition. Thus the legal framework designed to facilitate access and maintenance would not be destroyed. Also, the assessment obligation of either the unit owner or the owner of the undivided interest would not be vitiated by sale. ${ }^{B 6}$ Finally, the possibility that the non-occupant grantee could share in the use of the common areas such as a pool could be eliminated by making the sale of the undivided interest subject to the first refusal option. ${ }^{67}$

\section{Provisions for Management}

Absent an agreement to the contrary, one co-tenant cannot contract for the other co-tenants, ${ }^{68}$ nor is he entitled to compensation for managing the property ${ }^{60}$ or to contribution for expenses incurred in improving the property. ${ }^{70}$ Therefore, in condominium plans, extensive management provisions have been included in the declaration of covenants to enable a central authority to maintain the common parts and provide common services. ${ }^{71}$ The tenant-owners agree that the building will be operated and maintained by a managment body, either a manager or board of inanagers, elected annually by the tenant-owners, ${ }^{72}$ or a non-profit corporation whose members are the unit owners. ${ }^{73}$ In either case, the management body is the agent of the unit owners acting under authority expressly delegated to it in the declaration. Generally, the body has the authority to enter into all contracts necessary for the efficient operation of the building. The unit owners retain some con-

64 See, e.g., Reed v. Spier, 27 Cal. 57 (1864); Stark v. Barrett, 15 Cal. 361 (1860).

${ }^{65}$ See discussion in part III, A, 4(a) infra.

66 See id. This can be assured by explicitly stating the percentage value attributable to each separately owned unit and to each undivided interest.

67 See discussion at III, A, 3 (a) infra.

68 Pearis v. Covillaud, 6 Cal. 617 (1856) ; Culp v. Webster, 25 Cal. App. $2 d$ 759, 70 P.2d 273 (1937); Swartzbaugh v. Sampson, 11 Cal. App. 2d 451, 54 P.2d 73 (1936); 2 AMrerucaN LAW OF PROPERTY $\$ 6.18$.

69 Howard v. Throckmorton, 59 Cal. 79 (1881); Steeve v. Yaeger, 145 Cal. App. 2d 455, 302 P.2d 704 (1956); Combs v. Ritter, 100 Cal. App. 2d 315, 223 P.2d 505 (1950); 2 AMarrican LAW OF PROPERTY \&6.18.

70 Higgins v. Eva, 204 Cal. 231, 267 Pac. 1081 (1928); Robinson v. Bledsoe, 23 Cal. App. 687, 139 Pac. 245 (1914); 2 Amertcan Law of Property § 6.18; Freencan, Cotenancy \& Partition § 262 (2d ed. 1886).

71 Some critics of condominium have expressed doubt about the validity of this delegation of authority, but the authorities clearly show that the management of a cotenancy may be delegated. See, e.g., Hammond v. McArthur, 30 Cal.2d 512, 183 P.2d 1 (1947); Spahn v. Spahn, 70 Cal. App. 2d 791, 162 P.2d 53 (1945) ; 2 AMrerrchn LAW of Property \$ 6.18; FreEMaA, Cotenancy \& Partition \& 164 (2d ed. 1886). Furthermore, that the matters subject to delegation may be controlled by the will of the majority is clear from cases involving unincorporated associations. DeMille v. American Fed'n of Radio Artists, 31 Cal. 2d 139, 187 P.2d 769 (1947).

72 Voting rights are allocated according either to the proportionate value of the unit or to the number of umits held by the individual. At present the corporation commissioner requires the latter method to be used. See discussion at IV, B, 2 infra concerning whether the corporation commissioner has jurisdiction over the sale of condominiums.

${ }^{73}$ A non-profit corporation offers the advantage of having much of its procedure codified in the California Corporations Code. However, there are disadvantages in using an unincorporated management body. See note 92 infra. 
trol through the right to direct the activities of the manager by appropriate resolution or at least through the right to remove those in charge.

To provide funds for the payment of management expenses the management body is authorized to assess the individual owners. These assessments are determined at an annual meeting and are apportioned among the owners according to a standard set out in the declaration. The owners are then required to pay in monthly installments. ${ }^{74}$

The purpose of these provisions is to provide the same efficient management that is achieved by a stock cooperative. But the fact that each tenant-owner in a condominium has a direct fee interest in the land and inprovements rather than a derivative shareholder interest in a corporation results in several differences in the enforcement of the provisions and in the liability of the parties.

\section{a. Enforcement}

As has been pointed out, the costs of operating and managing the building are paid out of a maintenance fund. In both the stock cooperative and the condominium this fund is maintained by assessment. If a party fails to pay the assessments, his share of the burden is shifted to the other owners or tenants until the default is cured. Therefore, effective enforcement of the covenant to pay the assessments demands that any breach thereof be speedily remedied.

It appears that the stock cooperative is superior in this respect. The lease is generally made conditional upon the occurrence of any of several significant conditions, which usually mclude breach of any of the covenants that are contained in the typical condominium declaration. ${ }^{75}$ If any enumerated condition does occur the lessor-corporation may exercise the summary remedy available to ${ }^{7 t^{76}}$ upon compliance with a short notice requirement. ${ }^{77}$ The corporation is then free to sell, lease, or rent the premises to another party within a relatively short period of time, ${ }^{78}$ thereby removing the financial burden imposed on the non-breaching tenant-shareholders. It may also bring a personal action against the breaching party to recover any amount due. ${ }^{79}$

In a condominium, on the other hand, the nanagement body may be left only with the remedies provided for breach of covenant. Enforcement can be improved by reserving a lien on each owner's interest to secure his obligation to pay assessments. ${ }^{80}$ In that case, failure to pay an assessment would give the lien holder or

74 The management body is also given the authority to assess specially for any unforeseen necessity. In this case the burden is also borne proportionately, unless less than all of the tenantowners are responsible for the debt.

75 E.g., VoGEL app. A, $\S 18$, which enumerates numerous conditions precedent to a determination to expire the lease.

76 Cad. Code Crv. Proc. \$ 1161 (unlawful detainer); Cax. CTv. Code § 791 (right of reentry).

77 Both summary remedies require only three days notice.

78 The lessor may relet on its own account if it declares the lease terminated, or it may take possession as agent of the lessee and hold the latter responsible for any deficit during the remainder of the term. E.g., Dethart v. Allen, 26 Cal.2d 829, 161 P.2d 453 (1945).

79 Cad. Code Crv. Proc. \$ 1174.

80 There is no question as to the validity of such a hen. The underlying obligation required by the Civil Code $\$ 2872$ need not be in existence at the time the lien is reserved. CaI. Crv. CODE § 2884. E.g., In re Bangle, 54 Cal. App. 415, 201 Pac. 968 (1921) (lien on property to secure performance of covenant to pay specified sum for future improvements held valid); see also Willys v. Pierce, 140 Cal. App. 2d 826, 296 P.2d 25 (1956) (deed of trust as security for performance of rent obligation is valid lien). 
his assignees (the other owners) ${ }^{81}$ the right to foreclose on the defaulting party's interest. ${ }^{82}$

Even with this, the enforcement may not fully protect the owners. Judicial foreclosure generally takes from six to eighteen months; ${ }^{83}$ it also results in additional costs, ${ }^{84}$ which may or may not be imposed on the breaching party..$^{85}$ In addition, the express reservation of a hen on an interest in real property is in effect a mortgage ${ }^{88}$ and therefore subject to the mortgage rules of debtor protection. ${ }^{87}$

More effective enforcement could be provided if a power of sale were attached to the liens reserved ${ }^{88}$ Pursuant to such a power, a private sale, eliminating court costs and attorney's fees and effective in three months and twenty days, ${ }^{80}$ could be held. ${ }^{90}$ It may also be possible to waive the rules of debtor protection as long as the waiver occurs after the security transaction and for fair and equitable consideration. ${ }^{91}$

A lien with a power of sale is nearly as effective a remedy as the eviction power

81 Since the lien is incident to the obligation, it passes to the assignee or express beneficiary of the obligation. CAr. Crv. CoDE § 1084. E.g., Cockerell v. Title Ins. \& Trust Co., 42 Cal. 2d 284, 267 P.2d 16 (1954).

82 Other remedies at law or equity are also expressly retaincd. See, e.g., $\$ 11$ of Declaration of Covenants, Conditions \& Restrictions, Palo Alto Estates. As to the validity of such a provision see note 87 infra.

83 Interview With Alvin T. Levitt, Menber San Francisco Bar, San Francisco, Nov. 13, 1961.

84 Court costs and attorney's fees.

85 They may be imposed if specifically stated in the note or in the sccurity instrument. Huber v. Sliedoudy, $180 \mathrm{Cal} .311,181$ Pac. 63 (1919); Leahy v. Warden, 163 Cal. 178, 124 Pac. 825 (1912); McNamara v. Oakland Bldg. \& Loan Ass'n, 131 Cal. 336, 63 Pac. 670 (1901); Peachy v. Witter, 131 Cal. 316, 63 Pac. 648 (1901). But see Cax. Code Crv. Proc. \& 730, which authorizes the court to fix reasonable fees notwithstanding a contrary stipulation in the note or instrument.

86 E.g., Dingley v. Bank of Ventura, 57 Cal. 467 (1881).

87 CAL. CODE CTv. Proc. $\$ 726$ requires the mortgagee-lienholder to foreclose on the security before action on the obligation itself may be taken. $C f$. Willys v. Pierce, $140 \mathrm{Cal}$. App. 2d 826, 296 P.2d 25 (1956) (mortgagee may sue for rent and unlawful detainer after foreclosing on lien securing accrued and unpaid rent). CAI. CODE Crv. Proc. \$ 725a assures the mortgagor a one year statutory period of redemption during which the rents and profits of the property must be applied for his benefit should he redeem. Cax. Code Crv. Proc. \& 707. And Cax. Crv. CODE $\$ 2953$ invalidates any attempt to waive these and other rights of the mortgagor. (The latter section would curtail the scope of the rights reserved in addition to the lien. See note 82 supra.)

88 This is expressly authorized by CAI. Crv. Code $\$ 2932$.

${ }^{89}$ CAL. CIv. CODE $\$ 2924$ requires three months notice of default and twenty days notice of sale. The problem of accounting for rents and profits is also eliminated since there is no statutory right of redemption following a sale under a power.

${ }^{80}$ The effectiveness of this remedy is not reduced by the anti-deficiency statutes. CAL. CODE CIV. Proc. $\S 580(\mathrm{~b})$ is applicable only to purchase money mortgages. Section 580 (d), which prolibits actions on notes secured by a mortgage with a power of sale, should not apply where the obligation is based on an assessment for maintenance. See Willys v. Pierce, 140 Cal. App. 2d 826,296 P.2d 25 (1956) (a lease is not a note). In any event, the probability of a deficiency arising following foreclosure of a condominium unit for failure to pay the assessment obligation is remote.

91 Morello v. Metzenbaum, 25 Cal. 2d 494, 154 P.2d 670 (1944); Salter v. Ulrich, 22 Cal. 2d 263, 138 P.2d 7 (1943) ; Bradbury v. Davenport, 114 Cal. 593, 46 Pac. 1062 (1896); Watson v. Edwards, 105 Cal. 70, 38 Pac. 527 (1894). 
available to the stock cooperative. ${ }^{92}$ Where the breaching party is merely being recalcitrant, notice of sale is as great an impetus to perform as notice of eviction. On the other hand, where he is simply financially unable to pay, the three month power of sale period would impose a greater burden on the other owners than would the shorter summary remedy period. This difference, however, is justified since the purpose of condominium is to give the tenant-owners the advantages of home ownership. Any attempt to provide a shorter period of enforcement would necessitate the establishment of soniething similar to a landlord-tenant relationship.

\section{b. Liability of Tenant-Owners}

Apart from the difficulties that may be involved in the collection of assessments, the condominium plan of management presents dangers of unexpected individual tenant-owner liability. It is possible that under this form of management the tenant-owners could be subject to (1) continuing contractual liability on their covenants after sale of their interest; and (2) unlimited personal liability in both tort and contract.

\section{(1) Continuing Liability}

The grantee of an estate in real property (either fee or leasehold) is bound by covenants contained in the instrument of conveyance. Assignment of the estate without release from the covenant would not absolve him from continuing liability..$^{83}$

Cooperatives solve this problem by providing that the tenant-shareholder may cancel his lease so long as he gives notice and keeps up his monthly assessments

02 It should be noted that there may be a way for a tenant-owner to avoid this summary remedy for collection of assessments. Since the hen has no effect until the obligation to pay arises and since the obligation to pay may arise only after the assessment is made by the manager, a financially distressed tenant-owner may try to gain time by revoking the manager's authority to assess him. If the revocation is valid the manager is merely left with a breach of contract action against the defaulting tenant-owner.

There are two possible methods of avoiding this dilemma: (1) argue that the obligation to pay exists from the first day the apartment is sold to the tenant-owner and that assessment is merely the ministerial act of determining the amount of the existing obligation; (2) make the assessment power irrevocable. An agency power coupled with an interest in the subject of the agency is irrevocable. Lane Mortgage Co. v. Crenshaw, 93 Cal. App. 411, 269 Pac. 672 (1928); MECHEM, OUtzINES OF THE LAW OF AGENCY \$\$ 264-71 (4th ed. 1952). A manager who is also a tenant-owner has an interest in the subject of the agency since he is an owner of the building, but an incorporated manageunent body or professional management firm has no such interest. Thus, if one of the latter two forms is used, it would be advisable to leave the power of assessment in a responsible tenant-owner so that the irrevocable agency rationale will still be available.

83 If the grantee signs the instrument he is clearly bound eontractually to the grantor. (In a condominiun the tenant-owners would also be contractually bound to each other. See note 160 infra.) Contractual obligations are not absolved by assignment. CAI. CIV. CODE § $145 \%$. Some attorneys feel that this continuing contractual liability would not exist if a deed poll were used. However, the majority rule is that the acceptance of a deed poll is equivalent to a contract on the part of the grantee to perform the covenants contained in the deed. See, e.g., Sexauer v. Wilson, 136 Iowa 357, 113 N.W. 941 (1907) ; Midland Ry. v. Fisher, 125 Ind. 19, 24 N.E. 756 (1890); Marshall v. Standard Oil Co., 17 Cal. App. 2d 19, 61 P.2d 520 (1936); 2 AMrericaN LAw of Property \$ 9.10. Contra, Dawson v. Western Md. Ry., 107 Md. 70, 68 Atl. 301 (1907). 
during the notice period. ${ }^{94}$ Although condominium plans as now drafted offer no solution to this problem, ${ }^{95}$ it could easily be avoided by providing in the declaration that the tenant-owner is bound on the covenants only so long as he owns the apartment.

\section{(2) Unlimited Liability}

In a cooperative, the nuanagement corporation does all of the contracting; thus the tenant-shareholders are insulated from third party claims. The tenant-shareholder's immunity is of no concern to the normal creditor, for he knows that the corporation as owner of the apartment building has more than sufficient assets to cover its debts. In a condominium, on the other hand, the tenant-owners merely form through their agreements an unincorporated association, which in itself offers no guaranty of limited liability.96

There are, however, several methods by which the tenant-owners may be able to provide protection nearly equal to that given by the cooperative: (1) the management may be incorporated and contracts made solely between it and third parties; ${ }^{97}(2)$ the declaration could contain a clause preventing the manager from pledging the personal credit of the tenant-owner unless he has written consent to do so; ${ }^{98}$ and (3) the manager may persuade the contractor to agree to look only to the mamtenance fund for satisfaction of the obligation. ${ }^{90}$

Where these methods are inapplicable or unavailable, the tenant-owners may be subjected to unexpected liabilities. Generally, members of an unincorporated association are hable as principals on all duly authorized contracts made by officers

04 In general the shareholder-tenant must give from nime to twenty-one months notice, depending upon the form of the instrument and the time of year that notice is tendered. E.g., VoGEL app. A, § 20.

95 In this situation the rule is that the implicit intention of the parties will govern. RestateMENT, Property § 538 (1944). Most courts have been quick to find that continuing hability was not intended. See, e.g., Bolles v. Pecos Irr. Co., 23 N.M. 32, 167 Pac. 280 (1917); Sexauer v. Wilson, 136 Iowa 357, 113 N.W. 941 (1907) ; 2 AMERICAN LAW OF Property \& 9.18. Unfortunately, California appears to be quite strict on this point, having held in every case that continuing liability was intended. Barrows v. Jackson, 112 Cal. App. 2d 534, 247 P.2d 99 (1952); Pratt-Low Preserving Co. v. Evans, 55 Cal. App. 2d 724, 204 Pac. 241 (1921) ; Califormia Packing Corp. v. Grove, 51 Cal. App. 253, 196 Pac. 891 (1921).

${ }^{96}$ See note 100 infra.

${ }^{97}$ Since such contracts will be made for the benefit of the tenant-owners, it is likely that they would still be liable as undisclosed or partially disclosed principals. See Shamhan v. Wells, 197 Cal. 716, 242 Pac. 483 (1925). See generally MecheM, OUtLInes of tHe LAw of Aaency $\$ \S 294-99$ (4th ed. 1952). Furthermore, if the management corporation were undercapitalized, the court would probably pierce the corporate veil. See Automotriz Del Golfo De California v. Resnick, $47 \mathrm{Cal} .2 \mathrm{~d}$ 792, 306 P.2d 1 (1957) ; BaLlantine, Corporations 302 (rev. ed. 1946).

08 See McCabe v. Goodfellow, 133 N.Y. 89, 30 N.E. 728 (1892); Davis v. Young, 9 Misc. 2d 209, 123 N.Y.S. 363 (Sup. Ct. 1910). This alternative may already have been adopted by those declarations which give the manager authority "to obtain and pay for out of the management fund specific items and services." (Emphasis added.) However, if the manager did contract for something beyond the value of the management fund, the court might still hold the tenantowners liable on the theory that the manager had ostensible authority to so contract.

${ }^{90}$ See Warman Co. v. Redondo Beach Chamber of Commerce, 34 Cal. App. 37, 166 Pac. 856 (1917); MECHEM, OUTIINES OF THE LAW OF AGENCX $\$ 297$ (4th ed. 1952). Notwithstanding the efficacy of this or of the previous two methods of limiting liability, it is difficult to imagine a creditor doing business under any of them once he discovered that the management fund was the only asset available to satisfy the obligation. 
of the association. ${ }^{100}$ Contracts made for the benefit of all the tenant-owners could bind the tenant-owners to joint and several liability. ${ }^{101}$ But even if the contract were deemed to be joint, ${ }^{102}$ the procedural law of some states, such as California, would allow the aggrieved contractor to proceed against any single tenant-owner. ${ }^{103}$ Althougl such a tenant-owner miglit have a riglit to contribution from the other tenant-owners, ${ }^{104}$ le would have been put to the trouble of defending a lawsuit and of seeking to collect from his co-tenants.

In addition to the danger of contract liability, there is the threat of unlimited liability of the tenant-owner for injuries to third persons caused by unsafe conditions in the common areas, or by the acts of common servants.

In contrast to the cooperative, the tenant-owners in a condominium actually own the common parts of the building. Eacl has the occupant's duty of keeping the premises in reasonably safe condition for busmess invitees along with the lesser duties owed to licensees and trespassers. ${ }^{105}$ The tenant-owners may also have a duty to keep the common parts reasonably safe for every individual who lawfully enters upon the premises. ${ }^{108}$ Since these duties cannot be delegated, it would be no defense to maintain that an injury had occurred because of the manager's failure to keep the premises in proper repair. ${ }^{107}$

These duties are common to all tenant-owners, and liability for breach is joint and several. ${ }^{108}$ Thus, a prospective tenant-owner should be aware that he could be

100 Security First Nat'l Bank v. Cooper, 62 Cal. App. 2d 653, 145 P.2d 722 (1944); Burks v. Weast, 67 Cal. App. 745, 228 Pac. 541 (1924); Zimmerman v. Prior, 46 Cal. App. 40, 188 Pac. 836 (1920). See cases collected in 7 A.L.R. 222 (1920); 41 A.L.R. 754 (1926). See generally Comment, 42 Catrr. L. Rev. 812 (1954).

CAL. CoRp. CODE $\$ 21100$ might appear to modify this rule: "Members of a nonprofit association are not liable for ... habilities contracted ... by the association in the ... repair, or furnishings of buildings . . . to be used for the purposes of the association." (Emphasis added.) However, since the purpose of the association in a condominium is solely to manage a building owned by the tenant-owners, the statute probably does not apply because there is no building "used for the purposes of the association."

101 See Car. Crv. Code § 1659. But see CaL. Crv. Code § 1431.

102 See Car. Crv. Code $\$ 1431$.

103 Cax. Code Civ. Proc. $\$ 441$.

104 See Car. Crv. Code $\$ 1432$.

105 See generally Prosser, Torts ch. 15 (2d ed. 1955).

106 As to a landlord's duty, see Johnston v. De La Guerra Properties, 28 Cal. 2d 394, 170 P.2d 5 (1946) ; ProsSER, TORTS $\$ 80$ (2d ed. 1955). That the tenant-owners may have the duties of a landlord, see Taneian v. Meghrigian, 15 N.J. 277, 104 A.2d 689 (1957), where the court refused to apply the social guest doctrine to the guest of a resident landlord injured on the common stairway of an apartment house.

107 Brown v. George Pepperdine Foundation, 23 Cal. 2d 256, 143 P.2d 929 (1944); Prosser, TORTS $\$ 78$ (2d ed. 1955); Harper \& JaMres, TORTS $\$ 26.11$ (1956); RestateMment, TORTS $\$ 877$ (d) (1939).

108 Accord, Farrell v. Placer County, 23 Cal. 2d 624, 145 P.2d 570 (1944) (two counties held jointly and severally liable for breach of cominon duty to keep bridge in repair).

A few early cases and the present encyclopedias hold that breach of a common duty by cotenants results only in joint liability. See Low v. Mumford, 14 Johns. R. 426 (Sup. Ct. N.Y. 1817); Tandrup v. Sampsell, 234 III. 526, 85 N.E. 331 (1908); Sumner v. Tileston, 21 Mass. (4 Pick.) 307 (1826); Southland v. Hill, 44 Me. 92 (1857); 39 AM. Jur. Parties $\S 40$ (1942); 67 C.J.S. Parties $\$ 44$ (1950). However, the noted authorities on torts make no mention of this exception, and the more recent cases have expressly declined to follow it. See Myles v. Butler, 202 Tenn. 290, 304 S.W.2d 306 (1957); Katz v. Preston, 73 Ohio App. 154, 55 N.E.2d 141 (1943); Giles v. Johnson, 69 Ohio App. 19, 42 N.E.2d 689 (1941); Prosser, Joint Torts and Several Liability, 25 CALIF. L. REv. 413 (1937) ; 2 HARPER \& JAMES, ToRTS § 10.1 (1956) ; RESTATEMIENT, TORTS $\$ 878$, illus. 1 (1939). 
individually liable for injuries to third persons caused by failure to keep the building in a reasonably safe condition.

Similarly, since the servants (such as doormen and elevator operators) hired by the manager would be servants of the tenant-owners, ${ }^{100}$ they would be vicariously liable for the torts of the servants committed within the scope of employment. ${ }^{110}$ Here again the liability would be joint and several, ${ }^{111}$ and as in the case of contract liability, any single tenant-owner could be sued for the entire amount of injury. But in a tort suit the danger is greater because there may be no right to contribution. ${ }^{112}$

The present condominium plans attempt to avoid this problem by making insurance mandatory. However, there is still the possibility that claims may exceed the policy coverage, or that the policy could be void because of some defect in the application. To protect against this there should be some form of an indemnity agreement in the declaration. ${ }^{113}$

\section{Provisions Necessary to Preserve a Harmonious Environment}

With several owners living in close proximity to one another and sharing common facilities as well as the common obligations that arise, effective sanctions and safeguards must be provided to prevent any disturbance to that environment.

\section{a. The Right of First Refusal}

The first concern is to provide some manner of controlling who may become a tenant-owner. To accomplish this draftsmen have made the individual owner's right to sell, lease, or rent subject to a first refusal option. ${ }^{114}$ The inclusion of such a restriction is generally based on two grounds: financial responsibility of each occupant is requisite to effective maintenance; and socially compatible persons are desired as neighbors. The necessity of precluding those who do not meet these standards is justified since a considerable financial burden is involved, people are living close together, and common facilities are shared by all.

The validity of the economic and social considerations upon which this restriction is premised las been recognized. In a stock cooperative the right to sell stock

109 See CaI. Crv. Code $\$ 2351$; Malloy v. Fong, 37 Cal.2d 356, 232 P.2d 241 (1951); REstateMrent (SeCOND), Agency \$20, comment $e$ (1958).

110 Cal. Civ. Code $\$ 2338$. See generally Mechem, Outuines of the Law of Agency ch. 12 (4th ed. 1952).

One possible escape from this particular trap would be to hire out the task of managing the building to a professional management firm. In this case a strong argument could be made that the management firm was an imdependent contractor, and therefore its employees were not servants of the tenant-owners.

111 Hiner v. Olson, 23 Cal. App. 2d 227, 72 P.2d 390 (1937); Seaboard Air Line Ry. v. Ebert, 102 Fla. 641, 138 So. 4 (1931); Moore v. Southern R.R., 165 N.C. 439, 81 S.E. 603 (1914); Note, 32 Colom. L. Rev. 759 (1932). But see Mechem, OUtudnes of tHe LaW of AGENCY $\& 454$ (4th ed. 1952).

112 The common law allowed no contribution among joint tort-feasors. Prosser, Torrs $\$ 46$ (2d ed. 1955). Although California has statutorily modified the common-law rule, the statute requires that a money judgment be rendered against all those from whom contribution will be sought. Cal. Code Crv. Proc. $\$ 875$ (a). Since there appears to be no way to force the injured party to join all possible defendants, a single wealthy tenant-owner could conceivably, at the caprice of the plaintiff, be held for the entire amount of the judginent.

113 See CAI. Crv. CodE $\$ \S 2772-78$ as an example of statutes governing such agreements.

114 This is also called a pre-emption right. 6 AMERrCaN LAW OF Property $\$ 26.64$. It is not a contract option since it is not exercisable at the will of the holder. Berg, Long-Term Options and the Rule Against Perpeticities, 37 CaLIF. L. REv. 1 (1949) [hereinafter cited as BerG]. 
(to which a proprietary lease is incidental) is usually subject to a consent requirement. ${ }^{115}$ Such restrictions have generally been upheld on the theory that a closelyheld commercial corporation may protect itself against hostile and disinterested persons becoming part of management. 116 The application of this principle where there is no commercial purpose requiring harmony in management represents an extension of the doctrine that would seem to cover condominiums as well as stock cooperatives. The condominium is in substance no different from a stock cooperative-the occupancy interest and the related burdens of management are the same-and therefore should be entitled to the same protection. . $^{117}$

Nevertheless there exists a strong public policy in favor of free alienability of real property. ${ }^{118}$ Any direct restraint on the right of alienation is generally held to violate this policy and is declared void. ${ }^{119}$ Whether or not the condominium first refusal option would be held valid depends on the type of restraint-the manner in which it operates-and the degree of restraint-the extent to which it impedes alienability.

There are two general types of restramts: those that effect a destruction of title $^{120}$ and those that impose contractual hability. ${ }^{121}$ According to the general rule, the first type of restraint on the power to convey is invalid.22 Only promissory restraints, which merely impose contractual liability on the owner who conveys in violation of his covenant, may be upheld. ${ }^{123}$

Generally intent determines what type of restraint is involved. ${ }^{\mathbf{1 2 4}}$ Usually this intent is reflected in the language used in the particular instrument. ${ }^{125}$ Some condomimum declarations, however, do not employ any of the usual words or expres-

11568 Beacon St. v. Sohier, 289 Mass. 354, 194 N.E. 303 (1935) ; 1165 5th Ave. Corp v. Alger, 288 N.Y. 67, 41 N.E.2d 461 (1942) ; Weismer v. 791 Park Avenue Corp., 6 N.Y.2d 426, 190 N.Y.S.2d 70, 160 N.E.2d 720 (1959); Penthouse Property v. 1158 5th Ave., 256 App. Div. 685, 11 N.Y.S.2d 417 (1st Dept. 1939) ; Ontario Jockey Club v. McBride, 1927 A.C. 916 (Can.) ; Galbraith v. Madawaska Club, 23 D.L.R.2d 6 (Ont. 1960).

California also allows restrictions on stock transfers. CaI. CoRP. CODE $\$ \S 305(\mathrm{c}), 501(\mathrm{~g})$, 2403 (c), 9609; Vannucci v. Pedrini, 217 Cal. 138, 17 P.2d 706 (1932) (first refusal right to corporation and other shareholders upheld).

Restrictions on the right to assign the lease or to sublet have also been upheld where a landlord-tenant relationship existed. Randol v. Tatum, 98 Cal. 390, 33 Pac. 433 (1893) ; Richard v. Degen \& Brody, Inc., 181 Cal. App. 2d 289, 5 Cal. Rptr. 263 (1960); Kendis v. Cohn, 90 Cal. App. 41, 265 Pac. 844 (1928).

116 See Ballantine, Californta Corporation Laws $\$ 52$ (1949 ed.); 12 Fletcher, Private Corporatations \$\$ 5452-56 (perm. ed. rev. vol. 1957). See also Berg at 24-29. Some cases look through the corporate form, however, and base it on the social and economic considerations actually present. See, e.g., Gale v. York Center Community Co-op, 21 Ill. 2d 86, 171 N.E.2d 30 (1961) ; 68 Beacon St. v. Sohier, supra note 115.

117 See, e.g., Gale v. York Center Community Co-op, supra note 116.

118 For a discussion of the purpose and the development of the rule protecting this pohicy, see 6 AMIERICAN LAW OF PROPERTY \$§ 26.1-6.4.

$119 \mathrm{Id}$. at $\$ 26.24$. See also SIMEs \& SMITH \$ 1112.

120 See 6 American Law of Property \$\$ 26.7-6.8; Restatemant, Property \$ 404(a), (c) (1944).

121 See Restatement, Property \$ 404(b) (1944).

1226 Amtertcan Law of Property \$\$ 26.15-6.16, 26.19; Restatement, Property \$ 405 (1944). Accord, CAI. Crv. CODE \$ 711: "A condition restraining alienation, if repugnant to the interest created, is void." See note 135 infra for discussion of cases construing this section. But see Restatement, Property \$ 406 (1944).

1236 Amierican Law of Property \$ 26.11; Restatement, Property § 406 (1944).

1246 AdTERican LaW OF Property \$26.10.

125 See generally id. at $§ 26.11$ for the classification usually given to certain expressions. 
sions. ${ }^{126}$ The first refusal option is merely one of the covenants, conditions, and restrictions contained in the declaration incorporated in the deed. The consequence of selling, leasing, or renting without first submitting the offer to the other owners is generally not specified. ${ }^{127}$ Where intent is not clearly manifested, the courts usually avoid a destruction of title by finding a covenant which would qualify as a promissory restraint. ${ }^{128}$ But it would seem wise to avoid entirely the risk of having the restraint nullified by specifying that it is promissory.

Even if the restramt is found to be promissory, the extent to which it impedes alienability must be reasonable. ${ }^{129}$ The test of reasonableness requires that the individual loss resulting from impaired alienability be weighed against the benefits the restraint is designed to achieve. ${ }^{130}$ Where the restriction on alienability is limited in scope and duration and where there are valid social and economic reasons for it, restraints have been upheld. ${ }^{131}$

The first refusal option would seem to be reasonable under this test. First of all, it is limited in scope. It is not an option to purchase exercisable at the will of the holder nor does it limit the buyers to whom the person restricted may offer to sell. It is only a privilege that arises when the owner of the restricted interest decides to sell and obtains a bona fide offer. When the privilege does arise, it must be exercised at the price and on the terms that a third party has offered, not at a stipulated price or on fixed terms. ${ }^{132}$ The owner thus may decide to sell whenever he wants, and can do so at the prevailing market price. Secondly, the first refusal option is himited in duration because it must be exercised within a reasonable time. ${ }^{133}$ Moreover, the social and economic considerations justifying the need for

126 See, e.g., $\$ 21$ of Declaration of Covenants, Conditions, \& Restrictions, Palo Alto Estates: "Any owner who wishes to sell, lease, or rent ... shall ... give to each . . . owner written notice...."

127 But see $\$ \mathrm{~V}$ of Declaration of Covenants, Conditions, \& Restrictions, of The Terrace at Peacock Gap, Biscayne Drive, San Rafael, California, Filed of Record in Book 1406 at 526, Official Records of Marin County, California: "Any attempted sale or lease or sublease ... without prior offer ... shall be wholly null and void and shall confer no title or interest ...."

128 See, e.g., Hawley v. Kafitz, 148 Cal. 393, 83 Pac. 248 (1905).

1296 AMLERICAN LAW OF PROPERTY $\$ 26.63$; see generally id. $\$ \$ 26.14-6.36$.

1306 AMERTCAN LAW OF PROPERTY $\$ 26.63$.

131 It is on this ground that trusts, legal life estates, and conditional or determinable fees are valid even though they restrict free alienability. 6 AMrERICAN LAw OF ProperTy $\$ 26.25$; see generally $i d$. $\$ \S 26.23-6.29$. The cases permitting restrictions on stock transfers are an example clearly in point. See notes 115 and 116 supra.

132 See, e.g., $\$ 21$ of the Declaration of Covenants, Conditions, \& Restrictions, Palo Alto Estates.

Restatement, Property § 413(1) (1944) declares such a pre-emption valid. Accord, Weber v. Texas, 83 F.2d 807 (5th Cir.), cert. denied, 299 U.S. 561 (1936) (valid pre-emption: "at the best bona fide price offered by responsible third parties when and if offered for sale or transfer."). See also Berg at 439 ; Srares \& SMrtr $\$ 1154$.

${ }_{133}$ See, e.g., $\$ 21$ of Declaration of Covenants, Conditions, \& Restrictions, Palo Alto Estates (15 days).

The Restatentent imposes an additional time limitation. Since the right of first refusal is an option subject to a condition precedent (the desire to sell), it must not endure beyond the period of the rule against perpetuities. Restatement, Property $\$ 413$, comment $e, \S 393$, comment $f$ (1944). See, e.g., Alamo School Dist. v. Jones, 182 Cal. App. 2d 180, 6 Cal. Rptr. 272 (1960); see generally cases collected in Sames \& Surte \$1154; see also 6 Anserican Law of Propertx $\$ 24.56$ (contract options to purchase clearly within the rule). Contra, Weber v. Texas Co., 83 F.2d 807, 808 (5th Cir.), cert. denied, 299 U.S. 561 (1936) ("The [first refusal] option is within neither the purpose of nor the reason for the rule [against perpetuities] ... [It] is therefore not objectionable as a perpetuity"). See also BERG at 447, 6 AMERICAN LAw 
such a restriction are identical to those present in the stock cooperative where stronger restrictions have been upheld. ${ }^{134}$

In the majority of cases that have held a condition void because it violated the rule against restraints the restrictions were significantly greater in scope and effect. There was either a condition against alienation or a condition that consent of the grantor or liis successor be obtained, ${ }^{13 \bar{s}}$ or an option or pre-emption exercisable at a price not reflecting market value. ${ }^{136}$ Such restraints on the alienability of real property are not justified by policy. The condominium first refusal option, however, does not fall within either of the above categories, and courts sliould find it vahid. ${ }^{137}$

The Constitution may also prove a barrier to enforcement of the first refusal option. Thus, use of the first refusal option to prohibit sale or rental to a member of a minority class for a discrimimatory purpose will not be enforced judicially. 138 To come within this constitutional bar, however, it must be shown that the preeniption option was used for the purpose of discrimination. Since the option arises whien any offer of sale, lease, or rent is made, and not only when the offeree is a member of a minority group, there is seemingly no constitutional defect on its face. Proving in a particular case that the first refusal option was exercised for a discriminatory purpose would be difficult. Unless an unconstitutional purpose is to be presumed, the right of first refusal, by merely giving the owners the opportunity to meet any third party offer, provides an effective vehicle for the private enforcement of restrictions for what may be legitimate social reasons. ${ }^{138}$

of Property $\$ 26.65$, and Sanes \& SMrtr $\$ 1154$ suggesting that a reasonable restriction such as a pre-emption option at market price satisfies the rule against restraints and therefore should be valid even if unlimited in duration.

The rule against perpetuities may nevertheless be considered a factor in determining the reasonableness of the restraint. For this reason a clause limiting the applicability of the first refusal right to a period satisfying the rule is advisable.

134 See note 115 supra.

185 E.g., Los Angeles Inv. Co. v. Gary, 181 Cal. 680, 186 Pac. 596 (1919) (covenant that grantee shall not sell, lease, or rent to non-caucasian, breach of which gave rise to possibility of reverter in grantor); Bonnell v. McLaughlin, 173 Cal. 213, 159 Pac. 590 (1916) (condition that grantee shall not sell, mortgage, convey, or alienate without consent of grantor); Prey v. Stanley, $110 \mathrm{Cal}$. 423, 42 Pac. 908 (1895) (covenant that owner of property shall not sell or convey without the consent of a third party, breach of which results in forfeiture); Murray v. Green, 64 Cal. 363, 28 Pac. 118 (1883) (condition that grantee shall not have the power or authority to sell, convey, lease, or encumber without the written consent of grantor). See also cases collected in Sirres \& SNIrH § 1153.

It should be noted that each California case involved a condition or covenant that was directly repugnant to the interest conveyed and therefore clearly within the codified rule against restraints on alienation contained in CAL. Crv. CODE $\$ 711$. None were reasonable in extent. Language that any restriction is void is therefore dictum.

136 E.g., Maynard v. Polhemus, 74 Cal. 141, 15 Pac. 451 (1887); Kershner v. Hurlburt, 277 S.W.2d 619 (Mo. 1955); Brace v. Black, 51 N.J. Super. 572, 144 A.2d 385 (1958).

137 See, e.g., Laffan v. Naglee, 9 Cal. 662 (1858) which impliedly sanctioned a right of first refusal in holding that it was a valuable incident of a leasehold interest.

138 Neither a declaration of forfeiture (Hurd v. Hodge, 334 U.S. 24 (1948); Shelley v. Kraemer, 334 U.S. 1 (1948); Cumings v. Hokr, 31 Cal. 2d 844, 193 P.2d 742 (1948)), nor a suit for damage (Barrows v. Jackson, 346 U.S. 249 (1953)), may be enforced.

139 Resistance to upholding the first refusal option may be encountered, however, if it is first tested in a situation that appears to involve discrimination. Although it may be safe from attack on constitutional grounds because of the difficulty in proving discrimination, a court anxious to uphold public policy may look elsewhere in order to reach the result desired. It may look to the rule against restraints on alienation and apply it very broadly. Cf. Noble v. Alley, [1951] Can. Sup. Ct. 64, 1 D.L.R. 321. 
Even assuming the first refusal option is valid, it is not completely effective. It is expressly made inapplicable to any sale under a power or pursuant to judicial foreclosure. ${ }^{140}$ It is also inapplicable where the owner makes a gift, bequest, or devise. ${ }^{141}$ Further, since California would not allow a destruction of title for failure to comply with the pre-emption option, the holder or holders of the power would be left only with the remedy of injunction, or after sale, damages. ${ }^{142}$

The problem of satisfying the rule against restraints of alienation may be avoided by providing that no one may use or occupy any apartment without first obtaining the approval of a specified number of the owners. A long line of California cases has upheld restrictions on use and occupancy on the ground that they are not a direct restraint because they do not restrict the right to sell. ${ }^{143}$ Although the discriminatory purpose for which most of those clauses were designed now renders them invalid, ${ }^{144}$ the rationale upon which they were upheld is still viable. The grantor is recognized to have the right to impose conditions and restrictions on property conveyed, as long as they are lawful. ${ }^{145}$ Certainly the desire for financially responsible and socially harmonious neighbors is not an unlawful purpose. Assuming that reasonableness and good faith are exercised in approving or disapproving, such a restriction would probably be upheld. ${ }^{148}$

Even here the rule against restraints may be violated. Requiring subjective approval for occupancy by a new owner may be considered so significant an indirect restraint on alienation as to be void under the rule. The fact that a buyer could not ineet the approval of the owners and therefore would be unable to occupy the premises himself inay constitute a restraint on alienation. By restricting the class of buyers to those who meet the approval of the other owners, marketability, an aspect of unrestricted ahenability, is reduced. ${ }^{147}$ More serious, the purchaser, knowing that he may be unable to enjoy the property himself if lie fails to meet the condition of occupancy, would probably not be willing to pay the full market

140 See, e.g., $\$ 21$ of Declaration of Covenants, Conclitions, \& Restrictions, Palo Alto Estates; $\S \mathrm{V}$ of Declaration of Covenants, Conditions, \& Restrictions, The Terrace at Peacock Gap, supra note 127 . Leases for periods under two years or to family members are also excluded.

But all control is not lost. Even though a foreclosure under a power of sale occurs because the mortgagor is in default on his assessments, the other owners may exercise their right to cure default as junior hienors or bid in at the sale.

141 See ibid.

142 The remedy of damages may be rendered useless by statute. In California, for example, CAI. CIV. CODE $\$ 3300$ limits damages to the detriment proximately caused or likely to result. Section 3300 imposes definite standards of proof. Avoiding the burden of proof by establishing liquidated damages requires compliance with CAL. Crv. CoDE $\$ \S 1670,1671$. Obtaining adequate damages under either procedure is difficult.

143 Los Angeles Inv. Co. v. Gary, 181 Cal. 680, 186 Pac. 596 (1919); Wayt v. Patee, 205 Cal. 46, 269 Pac. 660 (1928); Fairchild v. Raines, 24 Cal. 2d 818, 151 P.2d 260 (1944) (reversed on other grounds); Cumings v. Hokr, 31 Cal. 2d 844, 193 P.2d 742 (1948) (reversed on other grounds); Title Guar. \& Trust Co. v. Garrott, 42 Cal. App. 152, 183 Pac. 470 (1919). Accord, Schulte v. Starks, 238 Mich. 102, 213 N.W. 102 (1927) (upholding restriction in deed that land should not be transferred to or occupied by "any person whose ownership or occupancy would be injurious to the locality"').

144 Sce Curmmings v. Hokr, supra note 143; CaL. Crv. CODE \$§ 53, 782.

145 See, e.g., Tennant v. John Tennant Memorial Home, 167 Cal. 570,140 Pac. 242 (1914);

Cornbleth v. Allen, 80 Cal. App. 459, 251 Pac. 87 (1926). Sce also CaL. Crv. Code \$ 1441.

146 See, e.g., Hannula v. Hacienda Homes, Inc., 34 Cal.2d 442, 211 P.2d 302 (1949).

1476 american Law of Property \$ 26.3. 
value. ${ }^{148}$ On the other hand, by conditioning purchase upon obtaining approval and by offering the assurance that undesirable neighbors will be precluded, the possibility of a restraint on alienation is eliminated.

\section{b. House Rules}

Maintaining harmony in a multi-family dwelling raises many problems beyond controlling ownership. As in a stock cooperative, basic rules concerning the use and occupation of a condominium unit must be established. Generally, the recorded declaration specifies that the compartment shall be used and occupied for residential purposes only; ${ }^{148}$ that nothing shall be done to obstruct the common areas ${ }^{150}$ or increase the rate of or result in the cancellation of insurance; ${ }^{151}$ that no nuisance or other annoying activity shall be carried on in the residence; ; $^{152}$ that no animals, except possibly normal household pets, shall be allowed without prior consent; ${ }^{153}$ that no waste or structural alteration shall be committed; ${ }^{154}$ and that no alteration shall be made to the exterior portions of the compartment that is out of harmony with the rest of the building. ${ }^{155}$

The priniary problem raised by these rules is providing adequate enforcement. In a stock cooperative, the remedy for breach is termination of the offender's lease. ${ }^{156}$ The present condominium declaration, on the other hand, merely allows the management body or any other tenant-owner to bring any action in law or equity that provides a remedy. ${ }^{157}$ This could include a nuisance action, or an action for breach of covenant. But nuisance may be difficult to establish in many cases ${ }^{168}$ and the contract remedy is inadequate because of the difficulty in proving damages and the delay.

More effective control could be obtained by niaking a violation of the use and occupancy rules terminate the fee interest. Perhaps more feasible would be to provide in the declaration for a schedule of fines and penalties assessable in a quasijudicial manner and secured by a lien on the interest of the breaching party. ${ }^{159}$

Whether either of these suggestions should be adopted depends upon the effect either might have in deterring potential purcliasers. The conflicting desires for speedy enforcement of the rules against other tenant-owners and freedom from interference with one's own activity indicate that a delicate balancing process is required.

148 See dissent in Los Angeles Inv. Co. v. Gary, 181 Cal. 680, 186 Pac. 596 (1919), where Angelotti, C.J., argued that the restriction on use and occupancy was directed against those who may use or occupy under the authority of the title owner and not the title owner himself without, however, considering it a restraint on alienation.

149 E.g., $\$ 12$ of Declaration of Covenants, Conditions, \& Restrictions, Palo Alto Estates.

150 Id. at $\S 13$.

151 Id. at $\S 14$.

152 Id. at $\$ 17$.

153 Id. at $\$ 16$.

$154 I d$. at $\$ 14$.

$155 I d$. at $\$ \S 15,18-20$.

158 See text at notes 75-77 supra.

157 See, e.g., $\$ 11$ of Declaration of Covenants, Conditions, \& Restrictions, Palo Alto Estates.

158 See Prosser, TorTs 410-11 (2d ed. 1955); see generally id. at §§ 72-74.

159 Fair standards for determining what conduct is to be penalized and in what amount should be set out in the declaration. This, of course, creates a burdensome practical problem. 


\section{Enforcement Against a Non-Signer}

It has been assumed in discussing the condorninium declaration that the tenantowners are bound by their covenants through privity of contract. ${ }^{160}$ This privity may not always exist; a tenant-owner inay sell without requiring his grantee to assent to the terms of the declaration; or a tenant-owner, dissatisfied with an ainendinent to the declaration, may assert that he is not bound by a contract to which he did not assent.

\section{a. The Non-Signing Subsequent Grantee}

To bind a subsequent grantee who does not assent to the terms of the declaration, some way must be found to make personal covenants run with an estate in real property without relying upon privity of contract. At present, condominium draftsmen are content to rely on the doctrine of equitable servitudes. ${ }^{161}$ Under this doctrine equitable remedies are available against a subsequent grantee with actual or constructive notice of his predecessor's covenant ${ }^{162}$ so long as present enforcement of the covenant is reasonable ${ }^{163}$ and the covenant was expressly made for the common benefit of all the units in the development. ${ }^{164}$ The agreements in the condominium declaration meet the requirement of notice through recordation; ${ }^{105}$ they are reasonable since by assuring effective management they enhance the value of the apartment house as a whole; and they provide the necessary expression of intent to benefit by specific introductory clauses to the declaration.

Restrictive covenants are clearly enforcible as equitable servitudes. Although some doubt has been expressed about the enforceability of covenants embodying affirmative obligations ${ }^{160}$ (such as assessments and covenants to repair) it seems

100 Although the agreements in the declaration are made between the grantor and grantec, specific introductory clauses make it clear that the grantees are bound to each other on the rationale that each is the third party beneficiary of the agreement of the other. See CAx. Crv. CODE \& 1559.

161 Remarks of Howard Ellman, Condominium Conference; Borgwardt, The Condominintm, 36 CAL. S.B.J. 603, 607 (1961).

162 See Wayt v. Patee, 205 Cal. 46, 269 Pac. 660 (1928).

163 See Los Angeles Terminal Land Co. v. Muir, 136 Cal. 36, 68 Pac. 308 (1902); Wing v. Forest Lawn Cemetery Ass'n, 15 Cal. 2d 472, 101 P.2d 1099 (1940).

164 See Werner v. Graham, 181 Cal. 174, 183 Pac. 945 (1919); McBride v. Freeman, 191 Cal. 152, 215 Pac. 678 (1923).

105 See note 162 supra.

166 See, e.g., Ames, Specific Performance For and Against Strangers to the Contract, 17 HARv. L. REv. 174 (1904); Stone, The Equitable Rights and Liabilities of Strangers to a Contract, 18 Colum. L. Rev. 291 (1918) (a reply to Ames); Lloyd, Enforcement of Afirmative Agreements Respecting the Use of Land, 14 VA. L. REv. 419 (1928). Contra, 4 Pomeroy, EQUITY JURISPRUDENCE § 1295 (5th ed. 1941).

The confusion concerning enforcement of affirmative obligations stems from the English case of Haywood v. The Brunswick Bldg. Soc'y, 8 Q.B.D. 403 (1881), in which the court held that a covenant to repair a building was not enforcible in equity because it involved an affirmative obligation. The case received hearty support from the noted American scholar Ames, supra, and was subsequently followed in New York. Miller v. Clary, 210 N.Y. 127, 102 N.E. 1114 (1913). Since that tine the distinction between negative and affirmative obligations has received severe criticisn and it is now safe to say that the great weight of authority in tbis country rejects the English rule. See cases collected in 41 A.I.R. 1363 (1926); 51 A.L.R. 1326 (1927) ; 118 A.L.R. 982 (1939); 68 A.L.R.2d 1022 (1959). What is more, New York has definitely receded from its original position. A recent lower court case seems to bave completely disregarded the rule by holding that an obligation to furnish heat to an adjoining building is enforcible as an equitable servitude. Atlas Land Corp. v. Ettinger, 283 App. Div. 379, 128 N.Y.S.2d 73 (1st Dept. 1954). 
clear that they are, at least in California. ${ }^{107}$ But the enforcement of agreements in condominium declarations is so crucial that all remedial theories should be explored even though it appears that the agreements are enforcible as equitable servitudes.

In Cahifornia, for example, the agreements could be treated as covenants running with the land and enforcible at law. Section 1462 of the Civil Code provides: "Every covenant contained in a grant of an estate in real property which is made for the direct benefit of the property . . . runs with the land." (Emphasis added.) The requirement that the covenant be "for the direct benefit of the property" makes this section inapplicable to purely burdensome covenants such as restrictions upon the use of the unit. ${ }^{168}$ However, since the tenant-owner's agreements to pay assessments and to insure and repair his unit are for the benefit of his interest in the condomimum, they slould run with the land under section $1462 .{ }^{169}$

Another possible method to inake the covenants enforcible at law against subsequent grantees is found in section 1468 of the Civil Code:

A covenant made by the owner of land with the owner of other land to do or refrain from doing some act on his own land, which doing or refraining is expressed to be for the benefit of the land of the covenantee, and which is made by the covenantor expressly for his assigns or to the assigns of the covenantee, runs with both parcels of land.

This code section could be applied to the restrictions on the use of the unit. Condominium draftsmen apparently have dismissed this section as a possibility because the section applies only to agreements entered into after the conveyance of the interest. ${ }^{170}$ But there is no reason why an attempt sliould not be made to have the tenant-owners execute such instruments after all of the units have been sold. In fact, it might be possible to make the signing of such agreements mandatory by providing in the grant deed that the fee will determine unless the grantee signs the specified instrument within a specified period after the last umit is sold.

\section{b. Amending the Declaration}

Because unforeseen problems may arise there must be some method of amending the rules under which the tenant-owners hive. There would be no problem with any amendment that received unanimous approval. Difficulty arises because many substantial changes would be opposed by some owners.

187 An obligation to pay money is enforcible in equity as a charge against the land. Fresno Canal \& Irrigation Co. v. Dunbar, 80 Cal. 530, 22 Pac. 275 (1889); In re Bangle, 54 Cal. App. 415, 201 Pac. 968 (1921). As to other affirmative obligations there appears to be no decision on point in this state. However, one decision bas recognized the majority rule and has indicated that it would be adopted if a proper case were presented. Coulter v. Sausalito Bay Water Co., 122 Cal. App. 480, 10 P.2d 780 (1932).

168 Marra v. Aetna Constr. Co., 15 Cal. 2d 375, 101 P.2d 490 (1940); Long v. Cramer Meat \& Packing Co., 155 Cal. 402, 101 Pac. 297 (1909).

169 Some writers assume that $\S 1462$ will not operate to make a burden run with the land. See 2 Witren, Sumomary of Calrfornia Law (Real Property) \$209 (7th ed. 1960). This is correct only if the burden is imposed by a covenant which confers no concomitant benefit on the land. See, e.g., Marra v. Aetna Constr. Co., 15 Cal. 2d 375, 101 P.2d 490 (1940), where the court expressly pointed out that the type of covenant rejected nnder $\S 1462$ is one "which in no way benefits the property." For authority that covenants which both benefit and burden will run with the land under $\$ 1462$, see Richardson v. Callahan, $213 \mathrm{Cal}$. 683, 3 P.2d 927 (1931); Washburn v. A.F. Gilmore Co., 116 Cal. App. 370, 2 P.2d 506 (1931). Althougb these cases deal with covenants in leaseholds, the court in each correctly applied $\$ 1462$ since a leasehold involves the "grant of an estate in real property." CaL. CIV. CoDE $\$ 761$.

170 Marra v. Aetna Constr. Co., 15 Cal. 2d 375, 101 P.2d 490 (1940) (\$ 1468 does not apply to covenants contained in a grant deed). 
In a cooperative there is no problem since it is commonly provided that all leases may be terminated, and thus re-written, upon the vote of a specified majority of the shareholders. ${ }^{171}$ Condominium draftsmen have attempted to simulate this arrangement by providing in the declaration that the tenant-owners agree to abide by any amendment assented to by a specified majority. There has been some concern over whether an individual's interest could thus be burdened by a restriction to which he does not consent. ${ }^{172}$

Enforcement against a tenant-owner who has agreed to abide by the will of the majority can be justified on purely contractual grounds. The law is replete with decisions in the area of unincorporated associations and mutual benefit societies holding that if an individual agrees to be bound by future amendments to the rules of the society, he will be bound, even though he dissents, as long as the amendment is reasonable and not against public policy. ${ }^{173}$ That real property is involved should be immaterial. The courts have held that property owners may bind themselves any way they wish through personal covenants as long as the covenants do not violate public policy. ${ }^{174}$

If the dissenting tenant-owner conveys his interest to one who agrees to abide by the decisions of the majority, the others need merely call a meeting and re-enact the disputed provision to bind the new tenant-owner, whether or not the disputed amendment ran with the land.

If the dissenting owner simply quitclaims his interest the problem is to bind the grantee by the agreement to abide by amendments. Arguably the grantee is bound because the covenant runs under the doctrine of equitable servitudes. ${ }^{175}$ The original grantee has made an agreement of which the subsequent grantee has notice. If the amendment is reasonable and for the benefit of the community as a whole there is no reason why a court of equity should not enforce it.

\section{c. An Alternative Solution}

The provisions of the declaration might be enforced against subsequent grantees who do not agree to comply with the terms of the declaration by compelling them to sign the declaration. If passage of title were conditioned upon signing the declaration, the method would probably be void as a restraint on ahienation. However, a restriction in the deed on who may occupy the property is not a restraint on ahenation in many states ${ }^{176}$ including California. ${ }^{177}$ Thus, the declaration could

171 See, e.g., VoGeI app. A, § 20(f).

172 Remarks of Howard Ellman, Condominium Conference; Borgwardt, The Condominium, 36 CAL. S.B.J. 603, 610 (1961).

173 See, e.g., Robinson v. Templar Lodge, No. 17, I.O.O.F., 117 Cal. 370, 49 Pac. 170 (1897); East-West Dairymen's Ass'n v. Dias, 59 Cal. App. 2d 437, 138 P.2d 772 (1943); Power v. Sheriff's Relief Ass'n, 57 Cal. App. 2d 350, 134 P.2d 827 (1943). But cf. Schack v. Supreme Lodge of the Fraternal Bhd., 9 Cal. App. 584, 99 Pac. 989 (1909).

174 Los Angeles Terminal Land Co. v. Muir, 136 Cal. 36, 68 Pac. 308 (1902).

175 In California this would be the only sound basis for making the covenants run. Civil Code $\$ 1468$ would not apply because the agreement is not one to do or refrain from doing something on the land. Civil Code $\$ 1462$ could be used if the agreement could be characterized as one for the direct benefit of the land. But this characterization would fail if the agreement were used to impose a restriction that was not for the direct henefit of the land.

178 See cases collected in 6 American Law of Property $\$ 26.34 ; 3$ A.L.R.2d 466, 491 (1949).

177 See Los Angeles Inv. Co. v. Gary, 181 Cal. 680, 186 Pac. 596 (1919); Wayt v. Patee, 205 Cal. 46, 269 Pac. 660 (1928); Littlejohns v. Henderson, 111 Cal. App. 115, 295 Pac. 95 (1931); Forest Lawn M.P. Ass'n v. De Jarnette, 79 Cal. App. 601, 250 Pac. 581 (1926). 
provide that no one may occupy a unit without first signing the declaration as duly amended. Any person failing to fulfill this covenant could be restrained from occupying the premises, ${ }^{178}$ and any person signing the declaration would be bound contractually by its provisions, thus obviating the problems of covenants running with the land. The only problem would be whether the restriction on occupancy itself runs. While it probably would run as an equitable servitude, ${ }^{179}$ it would assuredly run if it were cast in terms of a condition to the interest, with a right of re-entry for breach. ${ }^{180}$

\section{B. Home Ownership Advantages}

It is apparent that a cooperative does provide more efficient management and greater protection from third party claims. The cooperative, however, achieves this superiority through the legal mechanism of a commercial apartment, i.e., a landlord-tenant relationship. In doing so some of the basic attributes of home ownership are sacrificed. The purpose of a condominium is to preserve these attributes.

\section{Security of Interest}

A home owner is secure from eviction so long as he continues making his tax and mortgage payments. In a cooperative, on the other hand, generally a shareholdertenant can be evicted on a month's notice not only if he fails to meet his monthly payments ${ }^{181}$ but also if he is adjudicated a bankrupt or performs certain acts of bankruptcy, ${ }^{182}$ or if holders of eighty per cent of the capital stock determine him to be an undesirable lessee because of his "objectionable conduct." 183 While these covenants undoubtedly facilitate management, they could easily be used to evict a shareholder-tenant on unmeritorious grounds since nowhere in the lease is there a defintion of "objectionable conduct."

A condominium owner, on the other hand, is nearly as secure as a homeowner. He may be evicted only for failing to pay his monthly maintenance assessinents ${ }^{184}$ or for failing to meet his mortgage or tax obligations. Not all community apartment experts think this security of the condominium owner is an advantage. It is felt that it would be difficult to control tenant-owners who actually are guilty of objectionable conduct. ${ }^{185}$ However, as pointed out this problem could be substantially remedied by providing for a system of fines and penalties for objectionable conduct. ${ }^{186}$

\section{Financial Independence}

A home owner is not responsible for his neighbors' payment of property taxes or mortgage installments. In a cooperative, though, since the building and land are owned by a single entity, property taxes are assessed agamst the premises as a

178 See Wayt v. Patee, 205 Cal. 46, 269 Pac. 660 (1928).

170 Ibid.

180 As to use of conditions in deeds, see Simes, Restricting Land Use in California by Rights of Entry and Possibilities of Reverter, 13 Hastmas L.J. 293 (1962).

181 See, e.g., VoGeI app. A, § 18(d).

182 See, e.g., VogeL app. A, \& 18(b).

183 See, e.g., VogeI app. A, \$18(f).

184 Less than $20 \%$ of the monthly costs should be for maintenance. But to that extent the condominium owner is less secure from eviction than the home owner.

185 Interviews With Members of the Hawaiian and San Francisco Bars, Nov. \& Dec. 1961. One Hawaiian attorney stated that he had put together five cooperatives in his career and that in every one there was at least "one 'foul-ball' who had to be evicted."

186 See text at note 159 supra. 
whole. Also, the operation is financed by a single blanket mortgage. ${ }^{187}$ If one shareholder-tenant fails to meet his monthly assessments, the entire apartment house is subject to a single tax lien and foreclosure of the mortgage unless the other shareholder-tenants pay his share of these obligations.

In times of prosperity there is little problem with this mutual financial responsibility, for upon a tenant's default he is summarily evicted and his interest is sold to someone else who will assume the obligations. In time of acute economic distress there is a real danger. Not only may there be no market for the defaulting tenant's interest, but worse, the solvent tenants may be so financially pressed that they will be unable to make up the default of the insolvent tenants. Thus, a solvent tenant could lose his interest without ever liaving himself missed a single payment. As a matter of fact this is exactly what happened in the great depression of the thirties, where in some metropolitan areas fifty per cent to seventy-five per cent of the cooperatives failed. ${ }^{188}$ While the cooperative proponents rightly argue that such a depression is very unlikely to happen again, it is said that this danger acts as a major deterrent to many people who would otherwise buy into a community apartment. ${ }^{189}$

A condomimum allegedly avoids this deterrent to purchasers, because the interests of the individual owners will be separately taxed and financed.

\section{a. Separate Property Taxation}

The tenant-owner's right to separate property taxation will vary from state to state. The governing factor will be the state's policy toward the taxation of the two interests that make up condominium tenure-an undivided interest in the land and the common parts of the building, and a several interest in one unit.

Some courts have held that the burden of separately assessing undivided interests in real property is too great a burden for the state to bear, ${ }^{100}$ while others feel that separate assessment is the better pohicy. ${ }^{101}$ The weight of authority is that separate assessment should be within the assessor's discretion. ${ }^{102}$

California at one time permitted separate assessment of undivided interests at the owner's option, ${ }^{103}$ and its supreme court has indicated that such is the preferable mode. ${ }^{194}$ However, that court has also said that regardless of hardships the tax statutes must be followed. ${ }^{195}$

187 Separate financing could be arranged for cooperatives if the institutional lenders were willing to accept the stock and leasehold of a shareholder-tenant as security. That institutional lenders may take liens on leaseholds just as they take liens on fee interests see CAL. FIN. CODE $\$ \$ 1227,1413,7100$. One writer reports that an institutional lender has agreed to such a plan. RaMrsey, Condontminm: The New Look IN Co-ops 5 (1961). However, Mr. Ramsey has informed us that this particular project failed to reach completion for other reasons. Letter from Charles E. Ramsey to California Law Review, March 8, 1962.

Furthermore, there are definite advantages to financing through a blanket inortgage. See notes 9,11 supra.

188 Postwar Co-ops, 88 Architecturax F. 93 (1948). See Richeson, "Condominitum" Concept Avoids Co-ops' Problems, Honolulu Star-Bulletin, Dec. 26, 1961, p. 13, col. 7, who says such problems still arise in times of relatively good prosperity.

189 Remarks of David Robinson, Condominium Conference; Note, 61 Harv. L. REv. 1407, 1410 (1948).

180 E.g., Toothman v. Courtney, 62 W.Va. 167, 58 S.E. 915 (1907).

191 E.g., Russell v. Lang, 50 La. Ann. 37, 23 So. 113 (1898).

192 See cases collected in 80 A.L.R. 867 (1932).

193 Cal. Stat. 1861 ch. 401, \&33; People v. McEwen, 23 Cal. 54 (1863).

104 See People v. Shimmins, 42 Cal. 121 (1871).

105 People v. McEwen, 23 Cal. 54 (1893). 
Although there are no cases interpreting the present statutory scheme, a recent opinion of the California Attorney General states that while under present law the local assessors are permitted to assess separately an undivided interest in real property, the owners of such interests may not compel separate assessment if the assessor chooses to assess the property as a unit. ${ }^{196}$ To date many assessors have indicated that they would be amenable to separate assessment. ${ }^{197}$ But the institutional lenders ${ }^{198}$ as well as the FHA, ${ }^{199}$ are chary about operating under such assurance.

There are presently no statutes in California which allow the owner of an undivided interest to compel separate assessment of that interest. However, there is a scheme found in sections 2800 through 2808 of the Revenue and Taxation Code which gives a right of separate payment of taxes on certain interests when such interests have been combined with others in a single assessment. ${ }^{200}$ Section 2801 provides for the separate payment of taxes on any "parcel of real property" separately valued on the tax roles. A parcel may be separately valued under section 2803:

Any person showing evidence by presentation of a duly recorded deed ... of an interest in any parcel of real property, which does not have a separate valuation on the roll, and who is not the owner ... of the entire parcel as assessed, may apply to the tax collector to have the parcel separately valued on the roll for the purposes of paying current taxes. (Emphasis added.)

Thus, to have the right to separate valuation for an interest in real property (1) the petitioner must not be the owner of all the parcels contained in the original assessinent, and (2) his interest must be a "parcel of real property." The attorney general has concluded that the owner of an undivided interest meets neither of these tests. ${ }^{201}$

According to the opinion a cotenant, as part owner of an assessed parcel, does not qualify as a person "who is not the owner ... of the entire parcel as assessed." This seems erroneous. The cotenant's interest is not entire as that word is commonly understood. ${ }^{202}$ True, his interest is "undivided," but the essence of a cotenancy is division, even if it be legal and not physical division. Further, legislative history indicates that the purpose of this clause was to prevent separate valuation when the person seeking such action was the owner of all the parcels contained in the original assessinent. ${ }^{203}$ If an undivided interest is a parcel it would seem that the owner thereof is not the owner of all the other parcels.

The second leg of the attorney general's opimion is that the right to have a

18637 Ops. Cal. Atr'y Gen. 223 (1961).

197 Remarks of Forest Simoni, Condominium Conference. See Condominium Housing Could Be Another "First" For Richmond, Cal. Builder, Nov. 1961, at 12; State's Assessors Told: "Condominizums-Coming Our Way," id. at 13.

198 Interview With Charles E. McCarthy, Vice-President, Bank of America, San Francisco, Dec. 20, 1961.

109 See text at notes 254-59 infra.

200 CAI. REv. \& TAX. CODE $\$ 2807.3$ limits the efficacy of these sections as far as large condominiums are concerned. It provides in part: "No separate valuation shall be made ... dividing any piece of property separately assessed into more than ten parcels."

20137 Ops. CAL. ATT'Y GEN. 223, 227 (1961).

202 "Entire" is commonly defined as "complete in all parts" or "undivided." WeBsTER's New INTERNATIONAT DictionaRY (2d ed. 1960).

203 Senate Interim Committee on State and Local Taxation, A Legal History of Property Taxation in California, Part III, Appendix to the Journal of the Senate, vol.3, at 96 (1955). 
parcel separately valued does not include the right to have an undivided interest in a parcel separately valued, i.e., that an undivided interest is not a parcel. This interpretation of "parcel" finds support in other jurisdictions, ${ }^{204}$ and even though California has defined the term broadly it has never held it to encompass anything other than a unitary interest in real property. ${ }^{205}$

However, the meaning of "parcel" in section 2803 should not be decided without reference to the provisions of the Revenue and Taxation Code concerning redemption. ${ }^{206}$ In the opinion under discussion the attorney general held that the same considerations applying to tax payments also apply to redemption and that therefore a cotenant cannot redeem his undivided interest without redeeming the whole of the property. ${ }^{207}$ This is incorrect.

Section 4147 permits redemption of a parcel having a separate valuation on the tax rolls and section 4151 permits separate valuation of any parcel as long as certain requirements, identical with those in section 2803, are met. For purposes of the redemption sections, however, the legislature has expressly defined "parcel" to include "an undivided interest in real property."208 Thus if property held in cotenancy is sold for delinquent taxes a cotenant may still redeem his interest without redeeming the whole. 209

Since a cotenant may redeem his interest apart from the whole, it seems incongruous that he cannot prevent the act making redemption necessary by paying the amount due on his interest alone. On the other hand the fact that the direct analogue of section 4146 in the payment chapter, section 2800 , does not provide as section 4146 does that "parcel" includes "an undivided interest" may indicate that the legislature for some reason intended the difference between the chapters to exist.210

The justification given for refusing separate taxation of undivided interests is that it would increase assessors' administrative burdens. More tax bills would be necessary ${ }^{211}$ and difficult valuation problems would arise. ${ }^{212}$ However, if the tenant-owners could force assessors to separately assess the several interests in the building those reasons would no longer apply to condominiums. If the assessor continued to assess the common parts as a whole there would still be no fewer tax bills than if he taxed separately each tenant-owner's undivided interest along with his several interest. Furthermore, valuation would be extremely burdensome if each several interest and its corresponding undivided interest

204 E.g., Johnson v. Sirret, 153 N.Y. 51, 46 N.E. 1035 (1897) ; Big Lost River Irr. Co. v. Davidson, 21 Idaho 160, 121 Pac. 88 (1912).

205 See, e.g., Cowell v. Clark, 37 Cal. App. 2d 255, 99 P.2d 594 (1940) (mineral estate);

Los Angeles Pac. Co. v. Hubbard, 17 Cal. App. 646, 121 Pac. 306 (1911) (easement); Ors. Car.

ATT'Y GEN. 9020, dated Nov. 13, 1933.

${ }^{208}$ CaI. REV. \& TaX. Code $\$ \S 4146-55$.

20737 Ors. CaL. ATT'Y GeN. 223, 229 (1961).

208 CaL. Rev. \& TAX. CODE $\$ 4146$.

209 This statute is not contrary to the common-law rule that a redeeming cotenant redeems for the benefit of all the cotenants: in the situation under discussion the cotenant merely redecms his own interest. In the case cited by the attorney general, Willmon v. Koyer, $168 \mathrm{Cal}$. 369, 143 Pac. 694 (1914), the cotenant was seeking to redeem the entire piece of property and not just his own interest.

210 The Code Commissioners suggested as long ago as 1939 that the legislature amend $\S 2800$ to conform with $\S 4146$, but the legislature has so far dechined to take this advice. CarIformia Code Commassion, Proposed Revenue and Taxation Code 54 (1939).

211 See Toothman v. Courtney, 62 W.Va. 862, 58 S.E. 915 (1907).

212 Remarks of Fred Wanaka, Condominium Conference. 
were not assessed as a single parcel, because the assessor would have to value each individual unit and then subtract the sum of those values from the value of the building as a whole in order to arrive at the value of the common parts. On the other hand, if he chose to assess each undivided interest along with its corresponding several interest, he would merely have to value the building as a unit and then allocate to each tenant-owner an amount in proportion either to the original cost of the apartment ${ }^{213}$ or in proportion to the percentage each tenant-owner held in the common parts. ${ }^{214}$

No direct authority has been found dealing with the right to separate assessment of a part of a building. However, a policy in favor of such a right may be found in the cases involving assessinent of a building, a portion of which is exempt from taxation. ${ }^{215}$ There the owner of the non-exempt portion has been held entitled to separate assessment.

In California section 2800 would ordinarily block separate valuation of the condominium several interest: "For purposes of this chapter improvements are not a 'parcel' separate from the land on which they are situated." (Emphasis added.) ${ }^{216}$ However, by avoiding section 2800 , separate payment of the taxes on the several interest might still be available, since but for that section the several interest would meet the case law definition of a "parcel of real property" under sections 2801 and 2803.217 The purpose of the chapter is to allow "collection on part of an assessment." The legislative history of section 2800 indicates that its purpose is to prevent separate payment of taxes on improvements contained in a single assessment with the land on which they are situated. ${ }^{218}$ Thus, if the improvements were assessed apart from the land, section 2800 would not bar division of the improvements into separate parcels. Section 2188.2 offers a niethod for severing inprovements from the land for purposes of assessment. ${ }^{210}$ It provides:

Whenever improvements are owned by a person other than the owner of the land on which they are located, the owner of the improvements or the owner of the land on which they are located may file with the assessor a written statement before the lien date attesting to their separate ownership, in which event the land and improvements shall not be assessed to the same assessee.

213 E.g., Tax bill for John Doe $=$ Total tax bill $\times$ Cost of apartment to John Doe Sum of cost of all apartments. parts.

214 E.g., Tax bill for John Doe $=$ Total tax bill $\times$ Interest (\%) of John Doe in common

215 See, e.g., Proprietors of Meetinghouse in Lowell v. City of Lowell, 42 Mass. (Metc.) 538 (1840). Accord, Cedars of Lebanon Hosp. v. County of Los Angeles, 35 Cal. 2d 729, 221 P.2d 31 (1950). See cases collected at 159 A.L.R. 685 (1945). However, these cases may be distinguished on the ground that it was constitutionally necessary for the courts to decide that the portion of the building used for charitable purposes was exempt from taxation.

210 This statute should have no effect if separate valuation for the undivided interest is available and separate valuation is sought for both the several and undivided interests as a single parcel, since in this case the several interest is not being considered a "parcel separate from the land."

217 See note 205 supra.

218 Sections $2800-08$ are derived from Pohtical Code $\$ \$ 3747-47$ a (repealed Cal. Stat. 1939 ch. 154, $\$ 5002$ ) which provided for separate taxation of parcels of "land." When the Revenue and Taxation Code was drafted, "Iand" was changed to "real property." The Code Commissioners then suggested that because of this change $\$ 2800$ be added to the code. CaIIFORNIA Code Cominussion, Proposed Revenue and Taxation Code axv (1939).

$210 \mathrm{It}$ is interesting to note that $\$ 2188.2$ was enacted in 1947 , some eight years after the enactunent of $\$ 2800$. 
Under present plans condominium owners do not fit within this section since they are the owners of the land as well as the improvements. However, if the tenant-owners conveyed their several interests to straw men, these straw men would qualify under the section and could apply for separate assessment of the land and buildings. Following that each tenant-owner should be entitled to separate valuation of his several interest under section 2803.220

Even if the arguments for separate taxation fail, in California, at least, the tenant-owners are still protected from a blanket foreclosure through their right to separate redemption under sections 4146-55.221 Although this could cause some inconvenience, it offers as much protection as separate taxation.

\section{b. Separate Financing}

Even nore important than separate taxation is the security achieved through separate financing. Besides providing for nearly complete financial independence among the tenants separate financing greatly facilitates the resale of individual units. If a tenant in a cooperative is to realize lis equity upon resale either he must find a purchaser with sufficient cash for an outright purcliase or the cooperative itself must have a reserve available for financing new tenants. ${ }^{222}$ Few cooperatives would be able to maintain such a reserve, ${ }^{223}$ and cash buyers today are an oddity, the current resurgence of conservative political ideas notwithstanding. Therefore a shareholder-tenant will more than likely have to finance the new tenant himself through a conditional sale. Since home owners often need the cash from a sale of their old dwelling to purchase a new one, or for other purposes, it would be preferable if they could sell outright.

Separate financing is advantageous to lenders as well as to purchasers. Smaller lending institutions may directly participate in financing individual units, where they would not have financed the entire project. Large institutions niay spread their risk by buying a few units in several buildings, without the complications of laying some of the action off on other financiers. Furthermore, defaults would be more easily cured, since only sales of the defaulting tenants' units, not the entire building, would be required.

Condoninium separate financing is legally feasible if it is accepted that the tenant-owners' individual interests are legally recognized interests in real property ${ }^{224}$ As lias been pointed out they should be so characterized. Even so, separate financing cannot become a reality until the institutional lenders agree to carry it out. Although a number of savings and loan associations have agreed to take

220 One difficulty with this method is that a court might declare the straw man device a sham and treat the grantor as the owner of both parcels. See Houtz v. Hellman, 228 Mo. 655, 128 S.W. 1001 (1910); but see Pacific Royalty Co. v. Williams, 227 F.2d 49 (10th Cir. 1955). Further, CAL. REv. \& TAX. CODE $\$ 2807.3$ would prevent subdivision into more than ten parcels.

221 As long as the several interest is attached to an undivided interest in the land, there should be no problem with the requirement of $\$ 4146$ that improvements shall not be considered a parcel separate from the land on which they are situated.

222 California permits loans to shareholders if approved by a two-thirds class vote. Cax. CORP. CODE § 823. However, some states absolutely forbid such loans. E.g., N.Y. STOCK CoRP. LAW $\$ 59$.

223 The authors have found no such reserve in any cooperative.

224 See CAL. FIN. CoDE $\$ \S 1227,1413,7102$. One attorney felt that savings and loan associations might be prevented from accepting determinable fees as security since they may only take hens on "a fee title to real property." CAL. FIN. CODE $\$ 7100$. However, it seems well accepted that a "fee title" mcludes defeasible fees and is not limited to fee simple absolute. Restatement, Property § 14, comment (2) (1936). 
mortgages on individual condominium units, ${ }^{225}$ no bank inside the continental United States ${ }^{226}$ has wholeheartedly endorsed the idea. However, the Bank of America and the Wells Fargo Bank have recently agreed to take on the financing of a San Francisco condominium for experimental purposes. ${ }^{227}$

The reluctance of the institutional lenders stems from four distinct possibilities: that the management of condominiums would be incompetent; that the lenders would be subject to the will of the tenant majority upon foreclosure; that the premises would be taxed as a whole; and that condommiums would not be accepted by consumers. ${ }^{228}$ As condominium plans stand there is some justification for these fears. However, some of them could be alleviated by drafting changes.

Under the present declarations of covenants the tenant-owners have the option of either hiring professional management or managing the building themselves. The banks fear that as amateurs in the field the tenant-owners could easily erode the value of a project through inept management. Even if there were no physical damage done to the premises, poor management could give the project a reputation making the units practically uninarketable. This poses no real problem, however, because the possibility of amateur management could be avoided simply by requiring in the declaration of restrictions that the tenant-owners retain professional management.

During the period between foreclosure of a mortgage and resale of the unit, the lender (assuming it bought in at the sale) would be subject to the will of the majority as would any tenant-owner. Unscrupulous tenant-owners, realizing that the lender is only an interim owner, could temporarily inflate assessments to take advantage of the lender's deep pockets. Once the lender sold out the resulting surplus could either be refunded or used to offset future expenses, thus reducing monthly assessments for the remaining tenant-owners. This danger may also be eliminated through careful drafting. The declaration could contain a provision prohibiting the tenant-owners from assessing an institutional lender in excess of some average of the previous years' assessments. If the lender elected not to resell but to use or rent the unit for a period to recoup its investment the prohibition against excess assessment would not apply.

The remaiming misgivings of the institutional lenders cannot be allayed by altering the provisions of the condiminium declaration. No provision can prevent tax assessors from carrying out a policy of taxing condominiums as a whole. ${ }^{229}$ The lenders' greatest fear, that condoniniums will not be a commercial success, can only be met by proof that they are wrong.

The conclusion would seem to be that the whole-hearted support of institutional lenders will not be forthcoming until condominiums prove successful. This is unfortunate, because the success of condomimum may depend upon the lenders' support.

225 Remarks of Royce L. Slewing and R. Keith Dearth, Condominium Conference.

226 Banks have been lending on individual units in Puerto Rico for a number of years. Hearings Before a Subcommittee on Various Bills to Amend the Federal Housing Laws of the Senate Committee on Banking and Currency, 86th Cong., 2d Sess. 585 (1960).

227 Interview With Charles E. McCarthy, Vice-President, Bank of America, San Francisco, April 6, 1962.

228 Remarks of Carl Ahlberg, Charles E. McCarthy, Royce L. Slewing, R. Keith Dearth, Condominium Conference.

229 Recall, though, that since in California a tenant-owner may redeem his interest without redeeming the whole, this fear is unfounded as far as California condominiums are concerned. 


\section{c. FHA Condominium Mortgage Insurance}

The Housing Act of $1961,{ }^{230}$ extending FHA mortgage insurance to condominium projects, should encourage acceptance by the lending institutions. Section 234 of the act authorizes FHA insurance of first mortgages "given to secure the unpaid purchase price of a fee interest in, or a long term leasehold interest in, a one-family unit in a multi-family structure and an undivided interest in the common areas and facilities which serve the structure."231 This legislation was designed to stimulate the construction of privately owned dwelling units, ${ }^{232}$ including condominiums. 233

The procedure for obtaining a commitment from the FHA under section 234 and for receiving payment on the insured event involves more than merely coming within the definition in that section. The statute requires that the "insured family unit ${ }^{234}$ must be located in a multi-family structure ${ }^{235}$ which is or has been covered by a project mortgage ${ }^{236}$ insured by FHA."237 Thus, if a condominium project is contemplated, the lender must first obtain an FHA commitment under one of several sections other than section 234. Then he must apply under section 234 to convert the project mortgage to condorninium inortgages. Finally, certain conditions to the collection of FHA insurance are imposed. This procedure enables the FHA to inpose building, inspection, and appraisal requirements, ${ }^{238}$ and to control the amounts ${ }^{239}$ and terms ${ }^{240}$ of the condominium mortgages.

The only part of this procedure peculiar to condominium developments is the step converting the project mortgage to condominium mortgages. The mortgagors must first present a recorded and binding plan of apartment ownership, which must be approved by the FHA and certified by the mortgagee as acceptable. ${ }^{241}$ To gain FHA approval the plan must meet certain requirements designed to ensure that the condominium is administered in the best interests of the tenant-owners. Thus the plan must establish the rate of apportionment between tenant-owners by which obligations are to be allocated and voting carried on;242

230 National Housing Act $\$ \S 203-234,75$ Stat. 149-160 (1961), 12 U.S.C. $\$ \S 1715-1715 y$ (Supp. 1961).

231 National Housing Act $\$ 234$ (b), 75 Stat. 160 (1961), 12 U.S.C. § 1715y(b) (Supp. 1961). 232 National Housing Act $\$ 234$ (a), 75 Stat. 160 (1961), 12 U.S.C. 1715y(a) (Supp. 1961). 233 S. ReP. No. 281, 87th Cong., 1st Sess. (1961).

234 The individual apartment unit plus the proportionate undivided interest in the common parts. FHA Reg. \$234.1(j), 26 Fed. Reg. 7497 (1961).

235 It need only have two family units. FHA Reg. \$234.1(k), 27 Fed. Reg. 2601 (1962).

236 This refers to a inortgage insured under an appropriate section of the FHA multi-family housing programs covering a multi-family structure. FHA Reg. $\$ 234.1(\mathrm{~h}), 26$ Fed. Reg. 7497 (1961). The usual project nortgage will involve a $\$ 207$ program dealing with a rental or a $\$ 220$ project concerning an urban renewal. A $\$ 213$ community cooperative prograin is excluded. 237 FHA Reg. $\$ 234.26$ (a), 26 Fed. Reg. 7498 (1961).

238 Proceeding under an appropriate multi-family prograin results in the imposition of requirements pertaining to that program in addition to those imposed by $\S 234$. RAMSEX, CoNDOMINIUMS: THE NEW LOOK IN CO-OPS 16 (1961). The procedure also assures the existence of a qualified insured inortgage in the event conversion to condominium ownership fails. Interview With Jack Tuggle, Assistant FHA Administrator, San Francisco, April 23, 1962.

239 There are per rooun and per unit limits on four-room units. FHA Reg. $\$ 234.27$ (a) (3), (b), (c), (d), 26 Fed. Reg. 7498-99 (1961). There are also Ioan to value limitations. National Housing Act $\$ 234$ (c), 75 Stat. 160 (1961), 12 U.S.C. \& 1715y(c) (Supp. 1961). A maximum limitation of $\$ 25,000$ is also imposed. FHA Reg. $\$ 234.2 \%$ (a) (1), 26 Fed. Reg. 7498 (1961).

240 FHA Reg. $\$ 234.29,26$ Fed. Reg. 7499 (1961), establishes the interest limit; FHA Reg. $\S 234.25,26$ Fed. Reg. 7498 (1961) governs the maturity date.

241 FHA Reg. \$ 234.26(b), 26 Fed. Reg. 7498 (1961).

242 FHA Reg. $\$ 234.26$ (b) (6) (i), 26 Fed. Reg. 7499 (1961). This section also provides that the percentage apportioned to any simgle tenant-owner shall be subject to FHA approval, unless such owner shall be the FHA or the mortgagee. 
it must provide for automatic membership of each owner with automatic termination upon transfer to a new owner; ${ }^{243}$ it must prohibit any change in the plan without the prior approval of the FHA; $; 44$ and it must contain a regulatory agreement between the FHA and the association of owners giving the FHA the right to impose other conditions and requirements. 245

Assuming the ownership plan is approved and accepted, the lender must next present a conversion plan, which is the device for shifting from the original project to a condominium. This plan must provide for: The termination of the existing FHA insurance by payment in full of the existing mortgage or by approved voluntary termination; the release of each family unit from the existing project mortgage by payment on the outstanding balance of the mortgage or by mortgages equal to the amount of such balance attributable to the family unit; and the conveyance of eighty per cent (by value) of the family units to FHA approved owners. ${ }^{246}$

The requirement of an ownership plan may promote lender acceptance of condomimum mortgages, since an FHA controlled management should reduce the lenders' fears of inefficient management and possible oppression through over-assessment. ${ }^{247}$ However, this gain may be offset by an aversion to the administrative burden of processing two apphications, ${ }^{248}$ and the complexities of complying with the conditions of each. For example, a showing of the economic soundness of the project may be a prerequisite to obtaiming FHA project mortgage insurance. ${ }^{249}$ This has generally involved showing an expected reasonable margin of profit. However, an FHA spokesınan has indicated that advance sale of a sufficient number of units to satisfy the eighty per cent requirement will suffice if conversion to condomimium is contemplated..$^{250} \mathrm{~A}$ more serious problem occurs where only the minimum eighty per cent has been sold by the time of conversion. If the mortgagor is unable to qualify for insurance as a non-occupant owner ${ }^{251}$ of the unsold twenty per cent of the units and is unable to acquire conventional financing or to sell the umits, ${ }^{252}$ the project mortgage obligation allocable to that unsold twenty per cent will not be extinguished as is required. Although the statute and the regulations are unclear, this would probably result in failure of the plan. ${ }^{253}$

Even if the project qualifies and a section 234 commitment is obtained, the

243 FHA Reg. \$ 234.26(b) (6) (ii), 26 Fed. Reg. 7498 (1961).

244 FHA Reg. \$ 234.26(b) (7), 26 Fed. Reg. 7498 (1961).

245 FHA Reg. § 234.26(f), 26 Fed. Reg. 7498 (1961).

246 FHA Reg. \$ 234.26(c), 26 Fed. Reg. 7498 (1961).

247 See text at notes 228-29 supra.

248 Interview With Barett Scherman of Scherman Construction Co., San Leandro, California, Mar. 10, 1962.

249 E.g., FHA Reg. \$207.11, 26 Fed. Reg. 7431-32 (1961).

250 Remarks of Tom L. Davis, Condominium Conference.

251 See FHA Reg. \$ 234.26(e), 26 Fed. Reg. 7498 (1961).

252 The conversion plan does not require that the entire $80 \%$ be refinanced with FHA insured mortgages; it requires only that $80 \%$ of the umits qualify as single family residences and that the entire existing mortgage be terminated or refinanced. Interview With Jack Tuggle, supra note 238 .

${ }_{253}$ To avoid this result, the Regulations should be modified to require approval of a conversion plan that allows sufficient time to acquire the necessary funds to extinguish any unpaid balance on the existing mortgage. If immediate compliance is desirable to assure that the project is substantially a condominium (Interview With Jack Tuggle, supra note 238), that percentage of units sufficient to satisfy the deficiency should be allowed to qualify for FHA insured mortgage coverage. This is consistent with the fact that non-occupant mortgagors can now qualify. See note 251 supra. 
regulations, without specific enabling authority in the provisions of the act itself, establish conditions to collecting upon the insured event. When the mortgagor defaults and the value of the security is insufficient to satisfy the mortgage obligation, the mortgagee, before he can be paid by the FHA, must certify: (1) That the individual deed for the family unit is valid in the jurisdiction; (2) that the mortgagor has good and marketable title to the family unit; and (3) that local property taxes are assessed and levied against each family unit as a taxable entity and not against the multi-family structure as a whole. 254

The first requirement is simply a matter of description and form. There slould be no difficulty with the second requirement in any jurisdiction which "permit[s] the fee simple ownership of units in a multi-family structure without the benefit of specific enabling legislation,"255 or which has such enabling legislation. ${ }^{256}$

The separate taxation requirement, however, presents a problem, especially in those jurisdictions that leave separate assessment to the discretion of the local assessors. Where local law directs assessment on the building as a whole, FHA insurance is just not available. But where the assessor has discretion, the result could be disastrous to lenders relying on FHA insurance. If at the time the mortgagee attempts to collect on the FHA policy the assessor has switched to assessing the project as a whole, the FHA will not pay. ${ }^{257}$ Besides the loss of FHA insurance, the mortgagee, if a bank or other controlled lender, would be subject to penalties imposed for the violation of state and federal statutes restricting the loan value ratio of mortgages not covered by FHA. ${ }^{208}$ These risks would seem to preclude lender reliance on FHA insurance of condominium mortgages. ${ }^{260}$ The problem could be solved either by legislation directing separate taxation of condominium units, or by a change in the section 234 regulations.

\section{Income Tax Benefits}

Owning a home offers several significant tax advantages over renting or leasing. These same benefits should accrue to an owner of a condominium unit.

Under Internal Revenue Code section 1034 a home owner's gain on the sale of his residence need not be recognized if he invests it in a new residence ${ }^{200}$

254 FHA Reg. $\$ 234.26$ (d), 26 Fed. Reg. 7498 (1961). The requirement of separate property taxation has been made exceptionally clear in amendments to the regulations. FHA Reg. $\S 234.26$ (d) (3), 27 Fed. Reg. 773 (1962) ; FHA Reg. \$§ 234.273, 234.274, 27 Fed. Reg. 773 (1962).

The mortgagee must also certify that the family unit is in no way physically damaged. FHA Reg. \$\$ 234.270, 234.275, 27 Fed. Reg. 2601-02 (1962). Any damage will result in a decrease in the amount of insurance forthcoming. FHA Reg. \& 234.270 (b), 27 Fed. Reg. 2602 (1962).

255 Remarks of Tom Davis, Condominium Conference.

256 E.g., Arkansas and Hawaii. See note 61 supra.

257 This is the effect of the language of Regulations requiring the mortgagee to certify that the encumbered unit is separately assessed. See note 254 supra .

258 E.g., CAI. FIN. CODE $\$ \$ 1226(\mathrm{~h}), 1228(\mathrm{a})$; Blochinan Conımercial \& Sav. Bank v. F. G. Inv. Co., 177 Cal. 762, 171 Pac. 943 (1918) (violation of statute limiting loans gives state grounds to impose penalty).

250 Interview With Howard Ellman, Member of San Francisco Bar, San Francisco, March $30,1962$.

260 Gain realized from the sale of the old residence will be recognized to the extent the adjusted sales price thereof exceeds the cost of the new residence. INr. REv. CODE OF 1954, $\S 1034(\mathrm{a})$. The adjusted sales price includes the amount realized less the allowed selling expenses. INr. REv. CODE OF 1954, \& 1034(b). 
and if other conditions are met. ${ }^{261} \mathrm{~A}$ condominium unit meeting those conditions should qualify as a residence and entitle its owner to the same treatment. Although specifically covered by the same section, stock cooperative residents must meet further conditions to avoid recognition. ${ }^{262}$

A condominium owner should also be entitled to the deductions home owners are allowed to take, such as the deductions for property taxes ${ }^{263}$ and interest on mortgage indebtedness. ${ }^{264}$ Under section 216 of the Internal Revenue Code the tenant-shareholder of a stock cooperative may also take these deductions, but the section imposes several conditions that would not have to be met by a condominium owner. ${ }^{265}$

Most troublesome among these is the requirement that eighty per cent of the gross income of the corporation must be derived from the tenant-shareholders. ${ }^{266}$ Thus, deductions could be lost to the tenants if umits producing more than twenty per cent of the gross income could not be sold and instead were leased or rented. It also precludes the corporation from direct commercial use of the street level portion of the building. Stock cooperatives presently circumvent this problem by

261 The property sold and the property purchased both must have been used as the principal residence of the taxpayer. INT. REv. CODE of 1954, § 1034(a). The new residence must be purchased within the period beginning one year before the date of sale of the old residence and ending one year after such date. Ibid. See also INT. Rev. CoDE of 1954, §1034(c).

202 INT. REv. CODE of 1954, §1034(f) confers the same non-recognition treatment upon tenant-stockholders of a cooperative housing corporation if the principal residence test is met and if the conditions of $\$ 216$ of the Internal Revenue Code are satisfied. See note 265 infra. In addition, the cost of the new residence, for the purposes of determining the amount reinvested, will include the amount paid for the stock and the proportion of the mortgage indebtedness allocated to the tenant-stockholder's apartment if the retention of the stock is subject to the payment thereof. Rev. Rul. 60-76, 1960-1 CUM. BuLx. 296.

203 Section 164 of the Internal Revenue Code allows a deduction for taxes paid or accrued: withm the taxable year. Treas. Reg. § 1.164-1 (1957), as amended, T.D. 6406, 1959-2 CuM. Burr. 66, prescribes that such taxes are deductible only by the person upon whom they are imposed. In the case of real property taxes, this is generally determined by the assessee of the tax rolls. 2 CCH 1962 Stand. FED. TAX REP. I1 1449.13. However, a co-owner of real property who has record title ownership may take a proportionate amount of the taxes as a deduction to the extent he pays them. 5 Mertens, Law of Federal Income Taxation $\$ 27.02$ (1956). A condominium owner therefore should be entitled to deduct the taxes paid by him if he either is assessed separately or pays the amount proportionate to his co-ownership materest in the property held in common.

264 Section 163(a) of the Internal Revenue Code allows as a deduction "all interest paid or accrued within the taxable year on indebtedness." Treas. Reg. $\$ 1.163-1(b)$ (1959) provides that a taxpayer may deduct interest paid on a mortgage upon real property of which he is the legal or equitable owner, as long as it is his indebtedness. See 2 CCH 1962 STAND. FEd. TAX REP. I 1400. Thus, where a condominium owner incurs an obligation for which his fee interest is security, he should be entitled to a deduction for interest paid.

205 Section 216 of the Internal Revenue Code provides that the cooperative housing corporation must only have one class of stock; each stockholder inust be entitled to occupancy by reason of stock ownership, and not entitled to any distribution except upon liquidation.

In addition, $80 \%$ of the gross income of the corporation for the taxable year in which the tax and interest is paid or incurred must be derived from the tenant-stockholders. The tenantstockholder inust ineet the statutory definition of $\$ 216(\mathrm{~b})(2)$ and is allowed only his proportionate share of the deduction as defined in $\$ 216(\mathrm{~b})(3)$. Furthennore, the deductions are allowed only to the extent of the proportionate share paid or accrued by the corporation in the taxable year of the tenant-stockholder. Thus, where the tenant-stockholder and the corporation have taxable years ending on different dates, all anounts paid by the tenant-stockholder to the corporation cannot be deducted because it cannot be determined whether the corporation qualifies until the end of its taxable year. Rev. Rul. 59-257, 1959-2 Cunc. Buxc. 101.

268 INT. Rev. CODE OF 1954, § 216 (b) (1) (D). 
selling the stock representing any unsold units or commercial units to individuals designated by the corporation, who in turn are given the right to sub-lease. The purchaser pays the rent he receives to the corporation as rent, these payments thus being derived from "an individual who is a stockholder in a co-operative housing corporation, and whose stock is fully paid up . . ."2027 Although this device as yet has not been questioned by the Commissioner of Internal Revenue, it does appear vulnerable to attack. In any event, it is a problem that condominium owners will not face.

The condominium owner niay have other tax deductions not available to the tenant-stockholder of a stock cooperative. Thus, he may take an uninsured casualty loss under section 165 (c) (3) of the Internal Revenue Code, ${ }^{208}$ whereas the tenant-stockholder in the stock cooperative is limited to a long term capital loss under the worthless securities rule of section $165(\mathrm{~g}) .^{208}$

If a tenant-owner of a condominiun converts his unit into rental property, depreciation niay be available since he is allowed to depreciate property held for the production of income. ${ }^{270}$ This deduction has been denied to a tenant-shareholder in a stock cooperative because his interest is deemed to represent an investment in stock only, no part of which may be allocated to the lease incident to the stock. 271

Even though condominium results in some tax advantages to the individual owners, it may carry with it adverse tax consequences if the management body is considered an "association," i.e., taxable as a corporation. ${ }^{272}$ Such a finding could lead to taxation of the association to the extent it receives assessments or rent in excess of annual expenses. ${ }^{273}$ If an organization has more corporate than non-corporate characteristics it may be taxed as a corporation. 274 The Treasury Regulations establish six major characteristics by which an association is measured. ${ }^{275}$ Condominium unquestionably has three of those characteristics: associates, ${ }^{276}$ free transferability of interest, ${ }^{277}$ and continuity of life. ${ }^{278}$ On the other

267 INT. REV. CODE OF 1954, \$ 216(b) (2).

268 To determine the amount deductible see Treas. Reg. $\$ 1.165-7$ (1960).

269 Peake v. Commissioner, 19 CCH Tax Ct. Memo. 577 (1951) (tenant-stockholder's interest consists of stock rather than proprictary lease). Cf. Amen v. Commissioner, $7 \mathrm{CCH}$ Tax Ct. Memo. 577 (1948), aff'd per curiam, 177 F.2d 513 (2d Cir. 1949) (stock in cooperative acquired as incident to securing place to live is not a security investment for purposes of taking a loss).

270 Int. Rev. Code of 1954, § 167(a) (2) ; see generally 2 CCH 1962 Stand. Fed. TAX REp. II 1715.511 et seq.

271 Rev. Rul. 61-162, 1961 INT. REv. Buxl. No. 37, at 9. But see Amen v. Commissioner, supra note 269.

272 See INT. Rev. Cone of 1954, § 7701(a) (3).

273 E.g., Rev. Rul. 55-154, 1955-1 Cum. BuxL. 216; see also Rev. Rul. 56-225, 1956-1 CuMr. BuLx. 58.

274 Treas. Reg. $\$ 301.7701-2$ (a) (3) (1960) ; see, e.g., Morrissey v. Commissioner, 296 U.S. 344 (1935).

275 Treas. Reg. \& 301.7701-2(a) (1): “(i) Associates, (ii) an objective to carry on business and divide the gains therefrom, (iii) coutinuity of life, (iv) centralization of management, (v) liability for corporate debts limited to corporate property, and (vi) free transferability of interests."

276 Apparently this means simply a group of more than one.

277 An interest subject to limited restrictions, such as a first refusal option, still complics with this characteristic. Treas. Reg. \$ 301.7701-2(e)(2) (1960).

278 Treas. Reg. $\$ 301.7701-2$ (b) provides that there is continuity of life if the death, insanity, bankruptcy, retirement, resignation, or expulsion of any associate does not result in a dissolution, and if no member las the power to dissolve the arrangement. The provisions in the condominium declaration running with the land or binding as equitable scrvitudes would secm to provide sufficient continuity. 
hand, the owners do not have limited liability, ${ }^{279}$ and there may or may not be a profit objective or centralized management.

In the absence of an objective to carry on a business for joint profit there can be no taxation as a corporation even if all the other characteristics are present. ${ }^{280}$ However, the management body could show a profit in a given year, either because of receipts from ground floor rentals, or because of charges imposed on the owners for reserves for future expenditures. ${ }^{281}$ Since this "profit" would be applied for the benefit of the owners either currently or in the future, a profit objective may be found to exist. Thus, a majority of the major characteristics would be present, including the essential characteristic of profit, and taxation would result. ${ }^{282}$

If in a given case this possibility of adverse tax consequences is significant, certain steps could be taken to mimimize the taxable income of the association. Annual assessments should be geared to estimated annual expenditure, making a special assessment where more is needed and refunding extra assessments where not needed. ${ }^{283}$ This may not be completely effective in the case of assessments for capital expenditures, since the association's deduction may be limited to the currently depreciable portion of the expenditure. On the other hand, since the association's business is merely the collection of and disbursement of assessments to maintain property it does not own, the full deduction should be available regardless of the nature of the disbursement. ${ }^{284}$ It may also be argued that an assessment to the tenant-stockholders for capital expenditure is only a contribution of capital by the "shareholders" of the "association-corporation" and therefore not taxable.

In addition to minimizing the nuanagement body's surplus, the condomimum declaration should make clear that the elected management body is not to have what the regulations consider to be centralized management-the exclusive and independent authority to make all management decisions. ${ }^{285}$ This can easily be done in a condominium by expressly providing what is now provided by implication: that the tenant-owners may by majority vote direct the management body to carry out their will. ${ }^{286}$ Although with a profit motive the association would still have over half the attributes set out in the regulations, even without centralized management, the validity of the strict numerical test announced therein has not been judicially approved.

Regardless of the possibility of adverse income tax consequences, the tax benefits accruing to the owner of a condominium unit from the standpoint of the

270 See discussion at III, A, 2(b) (2) supra.

280 Treas. Reg. $\$ 301.7701-2$ (a) (2) (1960) states that "the absence of [either associates or an objective to carry on business for joint profit] will cause an arrangement among co-owners of property for the development of such property for the separate profit of each [or for no profit] not to be classified as an association."

281 See, e.g., the FHA's Sample Regulatory Agreement and Plan of Apartment Ownership, on file at the California Law Review, which the FHA may impose on a $\$ 234$ project.

282 See note 274 supra.

283 See Note, 61 HaRv. L. Rev. 1407, 1421-22 (1948) ; see also Rev. Rul. 56-225, 1956-1 Cuar. Burx. 58.

284 See note 273 supra. See also Ostrow v. Commissioner, $15 \mathrm{CCH}$ Tax Ct. Memo. 957 (1956) ; Park Lane Apartments v. Commissioner, CCH 1942 Stand. Fed. Tax Rep. Il 7591-A (B.T.A. Memo).

285 Treas. Reg. $\$ 301.7701-2$ (c) (1960).

286 See text at notes 71-74 supra.

An alternative solution would be to require the owner to ratify decisions involving expenditures above a certain amount and long term contracts or leases with third parties. See cases cited at note 284 supra. It should be noted that such a provision is principally formal. In practice, it should not put any strenuous management burden on the individual owners. 
deductions available to him make condominium more attractive than a stock cooperative. Moreover, the possibility of adverse income tax consequences, which the stock cooperative also faces, can be avoided if necessary.

\section{IV \\ THE DEVELOPER'S CONSTDERATIONS: \\ ADMINISTRATIVE REGULATION}

Whether a community apartment developer should choose the condominium or stock cooperative form of ownership depends largely on his analysis of consumer desires. However, the developer's choice is also affected by the degree of administrative regulation he expects to encounter with either form.

\section{A. Regulation of Construction}

Zoning legislation permitting the regulation of land uses exists throughout the country. ${ }^{287}$ The typical zoning ordinances enacted by local legislative bodies establish districts or zones of permissible use and in addition limit that use by regulations "relating to such items as residential density, building type, lot coverage, yards, building height, lot size, parking, and ratio of floor area to lot size."288 The local government also has the power to impose the cost of street and sewage construction, improvement, and repair upon the property owners benefited. ${ }^{289}$ The typical community apartment designed for high density areas, whether a stock cooperative or condominium, will be subject to control under either of these local powers.

A problem arises in those states that in addition have laws regulating the subdivision of property for development and sale.290 Although the scope and degree of subdivision control varies from state to state, ${ }^{201}$ the purpose is generally the same- "to give proper direction to community growth and development."202 The California Subdivision Map Act ${ }^{283}$ is a typical example of such regulation. It vests in the local governmental body the power to control the design and

2876 Poweit, Real Property § 868 (1959). See, e.g., CaL. Gov't Code $§ 65800$.

288 Fisher, Land Use Control Through Zoning: The San Francisco Experience, 13 Hastanos L.J. 322, 323 (1962). See, e.g., Clemons v. City of Los Angles, 36 Cal. 2d 95, 222 P.2d 439 (1950).

289 That this power exists with respect to charter cities and counties is clear. CaL. Consr. art. 11, § 6. See, e.g., Associated Homebuilders v. Livermore, 56 Cal. 2d 847, 366 P.2d 448, 17 Cal. Rptr. 5 (1961); San Jose v. Lynch, 4 Cal. 2d 760, 52 P.2d 919 (1935); Longridge Estates v. City of Los Angeles, 183 Cal. App. 2d 533, 6 Cal. Rptr. 900 (1960) ; Cramer v. San Diego, 164 Cal. App. 2d 168, 330 P.2d 235 (1958); Mefford v. Tulare, 102 Cal. App. 2d 919, 228 P.2d 847 (1951). See also Irish v. Hahn, 208 Cal. 339, 281 Pac. 385 (1929) ; Burnet v. City of Sacramento, 12 Cal. 76 (1859). General law cities and counties also have means of achieving such a result. See CaL. Const. art. 11, §11; CaL. Gov'T Code $\$ 43225$; Car. STREer \& H'ways CODE $\$ \S 1020,1128-30,4093-94,5100-01,5180,5610,5625-29,5875,5890-94$.

200 All states except Vermont have such regulations. HaAR, LAND-Use PLANnnga 349 (1959). 201 See the compilation of representative statutes in HAAR, op. cit. supra note 290, at 351-62. 292 Mansfield \& Sewett, Inc. v. Town of West Orange, 120 N.J.L. 145, 150, 198 A.2d 225, 229 (Sup. Ct. 1938).

293 CaI. Bus. \& Prof. Code $\$ \S 11500-641$. 
improvement of a subdivision and to adopt ordinances for those purposes. ${ }^{294}$ According to the act, "design" relates to the layout and size of streets, rights of way for drainage and sewers, and minimum lot sizes. 295 "Improvement" refers to the street work and utilities that will serve the owners in the subdivision and the local neighborhood. ${ }^{298}$

Condominium developers are being advised to proceed under the act because if it applies and is not complied with, any sale by a subdivider could be voided by the purchaser. ${ }^{297}$ The act apphes to "any real property, improved or unimproved, or portion thereof, shown on the latest adopted county tax roll as a unit or as contiguous units, which is divided for purpose of sale or lease, whether immediate or future, by any subdivision into five or more parcels within any one-year period."208 Since the "leasing of apartments . . . within an apartment building" is expressly excluded, ${ }^{299}$ stock cooperatives are not subject to the provisions of the act. Condominiun projects involving five or more units, being real property divided for purpose of sale, are literally within its scope. The developer must therefore prepare subdivision maps and obtain the approval of the local authorities by conforming to the conditions established by the act or by the subdivision ordinances regulating design and improvernent. ${ }^{300} \mathrm{He}$ thus may be forced to satisfy burdensome conditions pre-requisite to approval. ${ }^{301} \mathrm{He}$ also may be confronted with the fees and administrative steps involved in preparing maps and submitting them for approval to the appropriate local governing bodies. ${ }^{302}$

It is clear that the coverage of the Subdivision Map Act literally extends to condominium projects. It is not clear, however, whether the purpose of the act applies. The primary objective of the act is to regulate the size and layout of the streets, sewers, and lots that the subdivision will require and to place the burden of their construction upon the subdivider. ${ }^{303}$ Such regulation is generally applicable to a development of large spaces of open land. ${ }^{304}$ The typical high rise condominium designed for concentrated urban areas doss not seem to be in need

294 CaL. Bus. \& Prof. Code $\$ 11525$.

Another purpose of the Subdivision Map Act and subdivision regulation in general is to provide an easy and accurate system of description. Ogden, CaJIFORNIa REal Property Law $\$ 12.4$ (1956). This is no longer predominant since a record of survey map is now sufficient for purposes of description. CAL. Bus. \& Prof. Code $\$ 11535$ (c). But even if a subdivision map is desirable for description purposes, it may be filed independently of substantive subdivision regulation. CaL. Bus. \& Prof. Code \$ 11536.

295 Cal. Bus. \& Prof. Code $\$ 11510$.

296 Cal. Bus. \& Prof. Code \$ 11511.

297 CAL. Bus. \& Pror. CODE $\$ 11540$.

208 CAL. Bus. \& Prof. COde $\$ 11535$ (a).

299 Ibid.

300 Cat. Bus. \& Prof. Code $\$ 11526$.

301 See, e.g., Ayres v. City Council of City of Los Angeles, 34 Cal. 2d 31, 207 P.2d 1 (1949), where conditioning approval of the subdivision map upon the dedication of footage for street widening and extension and upon the restriction of a certain area for the planting of trees and shrubbery was held valid under the Subdivision Map Act. In one community, condominium projects were abandoned because of the burdensome nature of its subdivision regulations. Interview With Howard Ellman, Member of San Francisco Bar, San Francisco, Mar. 30, 1962. 302 See generally CaL. Bus. \& Pror. CODE \$§ 11500-641.

303 Kelber v. City of Upland, 155 Cal. App. 2d 631, 318 P.2d 561 (1957) ; Hoover v. Kern County, 118 Cal. App. 2d 139, 257 P.2d 492 (1953).

${ }^{304}$ See, e.g., Ayres v. City Council of City of Los Angeles, 34 Cal. 2d 31, 207 P.2d 1 (1949) (thirteen acre residential subdivision); Kelber v. City of Upland, 155 Cal. App. 2d 631, 318 P.2d 561 (1957) (fifteen acre residential subdivision). 
of such regulation. The application of specific zoning ordinances making possible a "plan for the physical development of the city, county, area or region,"305 in addition to the power to charge the cost of streets and sewers to the benefited property owners, could accomplish substantially the same result as does subdivision regulation..$^{306}$

There are indications that the Subdivision Map Act was not intended to apply to projects like condominiums. The Real Estate Law, ${ }^{307}$ which governs the marketing of subdivided lands, expressly includes in its definition of a subdivision "undivided interest[s] . . . coupled with the right of exclusive occupancy." The Subdivision Map Act, except for its omission of the quoted phrase, contains an otherwise identical definition. ${ }^{309}$ The different treatment seenis justified since community apartment projects and, a fortiori, condominiums, are clearly within the purpose of the Real Estate Law. Arguably, the failure to add the sanie provision in the Subdivision Map Act indicates that the legislature did not intend that act to apply. The express exemption in the Subdivision Map Act of "the leasing of apartments ... within an apartment building," 310 too, makes clear that an apartment building as such is not in need of the type of control that the Subdivision Map Act is designed to supply. ${ }^{311}$ Selling instead of leasing the apartments would not seem to increase the need for subdivision control. Until there is legislation making clear the application of the act to condominiums, however, developers would be well advised to comply with its provisions.

\section{B. Regulation of Sale}

In addition to regulation of construction, the community apartment developer must conform to the laws regulating the sale of the project. The stock cooperative must meet the requirements of the applicable state Blue Sky Law. Condominium, on the other hand, involves the sale of parcels of real property and therefore comes within the regulatory ambit of the Real Estate Laws of the various states. ${ }^{312}$ In

305 CAI. Gov'T Code $\$ 65460$. See generally CAL. Gov'T CODE $\$ \$ 65000-516,65800-051$; see also Miller v. Board of Public Works, 195 Cal. 477, 486, 234 Pac. 381, 384 (1925).

308 For a case indicating the manner in which zoning control can be used see Bringle v. Board of Supervisors, 54 Cal. 2d 86, 351 P.2d 765, 4 Cal. Rptr. 493 (1960).

307 CaI. Bus. \& Prof. CODE $\$ \$ 11000-202$.

308 Cal. Bus. \& Prof. Code $\S 11004$. See also 17 Ors. Cal. Atr'y Gen. 79 (1951).

309 Compare CaI. Bus. \& Prof. Code $\$ 11000$, with $\$ 11535$.

310 CaL. Bus. \& Prof. Code $\$ 11535$ (a).

311 Not only is a single apartment building exempt from the Subdivision Map Act, but also any development in which "(i) the whole parcel before division is less than 5 acres, (ii) each parcel created by the division abuts upon a public street or highway, (iii) no street or opening or widening, drainage facilities, or other improvements have been required by official action of the governing body, and (iv) the lot design meets the approval of the governing body." CaI. BUS. \& Pror. CODE $\$ 11535$ (b) (1). The typical high rise condominium cannot come within this exception because each parcel will not abut upon a public street or highway. California Attorney General Opinion No. 61-229 (Feb. 1962). A horizontal condominium does. See, e.g., the Terrace at Peacock Gap, supra note 127, where this exception is applied. The application of this exception thus indicates another situation where there is no need for subdivision control. 312 In Cahfornia, for example, the owner or subdivider of parcels of real property must submit certain information by notice of intention to sell or lease and by answers to a questionnaire. CAL. Bus. \& Prof. Code $\$ \$ 11010,11011$. No offer to sell or lease is permitted until a public report is issued (based upon the information obtained through the above procedure), and no sale or lease may be consummated unless a copy of the report has been given to the prospective purchaser or lessee. CAL. BUS. \& PROF. CODE \& 11018.1. Failure to comply may result in criminal penalties as well as conferring upon the purchaser or lessee the option to void the sale or lease. Car. Bus. \& Prof. CODE $\$ \$ 11019,11020$. 
some states, however, the sale of a condominium unit may also be treated as the sale of a security, and thus subject to regulation under the state Blue Sky Law. ${ }^{313}$ Merely because a condominium is an interest in real property does not necessarily preclude its being a security. ${ }^{314}$

Although no court has yet purported to set out a definitive test for determining what interests are securities, two essential characteristics have evolved: (1) purchasers must be led to invest with the expectancy of a return; and (2) the investor must intend to rely solely on the efforts of others to realize the return. ${ }^{315}$

Under the first test some courts have held that there is no security unless the investor is led to expect a money profit. ${ }^{316}$ But in California, under Silver Hills Country Club v. Sobieski, ${ }^{317}$ anticipation of money profit is no longer necessary. The first characterstic is present if at the time of sale some intangible benefit is expected and there is a substantial risk that the investment will be lost without realization of the expectancy.

The intention to rely on the efforts of others is often inferred by the courts if the investor cannot, ${ }^{318}$ or as a practical matter will not, ${ }^{319}$ take an active part in producing the expected benefit.

Whether the sale of a condominium unit has these essential characteristics may depend on the time of sale. Units are commonly sold before construction of the building. Although in that case condominium would not be a security in states requiring a money profit motive, ${ }^{320}$ the "risk capital" requirement of Silver Hills would be met: the investor expects that a building (country club) of a certain description will be built, and there is a risk that it may never be fimished, or that sufficient units (memberships) will not be sold to make it successful. ${ }^{321}$ Since the purchaser would have no control over sales or construction of the units, the second

313 Remarks of Herbert E. Wemig, Condominium Conference.

314 Real property interests have often been held to be securities. E.g., SEC v. W.J. Howey Co., 328 U.S. 293 (1946) ; SEC v. Jomer Corp., 320 U.S. 344 (1943); Oil Lease Serv. Inc. v. Stephenson, 162 Cal. App. 2d 100, 327 P.2d 628 (1958) ; People v. Yant, 26 Cal. App. 2d 725, 80 P.2d 506 (1938). Contra, State v. Hirsch, 101 Ohio App. 425, 131 NE.2d 419 (1956).

316 E.g., People v. Syde, 37 Cal. 2d 765, 235 P.2d 601 (1951); Austin v. Hallmark Oil Co., 21 Cal. 2d 718, 134 P.2d 777 (1943); Lewis v. Creasey Corp., 198 Ky. 409, 248 S.W. 1046 (1923); State v. Silberberg, 166 Ohio 101, 139 N.E.2d 342 (1956); Osuna v. Russell, 176 Cal. App. 2d 110, I Cal. Rptr. 289 (1959) ; People v. Steele, 2 Cal. App. 2d 370, 36 P.2d 40 (1934); 1 Loss, SeCURuTIES REGulation 491 (2d ed. 1961); Dahlquist, Regulation and Civil Liability Under the California Corporate Securities Act, 33 CarIF. L. REv. 343, 358 (1945).

316 E.g., Creasey Corp. v. Enz Bros. Co., 177 Wis. 49, 187 N.W. 666 (1922); Hacker v. Goldberg, 263 Ill. App. 73 (1931).

31755 Cal.2d 811, 361 P.2d 906, 13 Cal. Rptr. 186 (1961), noted in 50 CarIF. L. Rev. 156 (1962) (sale of memberships in a country club not yet in existence held to be the sale of securities).

318 See, e.g., SEC v. W.J. Howey Co., 328 U.S. 293 (1946); Domestic \& Foreign Petroleum Co. v. Long, 4 Cal. 2d 547, 51 P.2d 73 (1935).

319 See, e.g., SEC v. Jomer Corp., 320 U.S. 344 (1943) ; Blackwell v. Bentsen, 203 F.2d 690

(5th Cir. 1953); Ogier v. Pacific Oil \& Gas Corp., 132 Cal. App. 2d 496, 282 P.2d 574 (1955); Moore v. Stella, 52 Cal. App. 2d 766, 127 P.2d 300 (1942).

320 This statement assumes that the unit is being bought primarily for use as a residence and not for pecumary profit.

321 There are also the risks that the plan of operation will be defective and that the other tenant-owners will not cooperate in the management of the building. It is submitted, however, that these two risks are not within the rationale of Silver Hills. That decision implicitly excluded the sales of interests in existing facilities, where the risks of defective operation and failure of cooperation are also present. Silver Hills Country Club v. Sobieski, 55 Cal. 2d 811, 815, 361 P.2d 906, 908, 13 Cal. Rptr. 186, 188 (1961). 
characteristic would also be present. Therefore the sale of a condominium interest before construction and the sale of a substantial number of units would be a sale of a security, at least in Cahfornia.

This result might be avoided if the purchase price were put in escrow and not released until the building was finished and a substantial number of units were sold. This would minimize risks and should lead a court to find the first element absent. Sale before construction would not then be a sale of a security.

The sale of a condominiun interest after construction, if conditioned upon sale of a substantial number of units, would not have the expected profit characteristic, even under Silver Hills. ${ }^{322}$ And even if it did, it might not be the sale of a security, because arguably the second characteristic would be lacking.

Although in purchasing a community apartment one of the primary benefits expected is efficient nanagement by someone other than the purchaser, the tenantowner in a condominium does to sone extent rely on his own efforts to gain that benefit. He must mamtain his own apartment and he may participate in the upkeep of the comnion areas. ${ }^{323}$ Further, it is intended that as a practical matter he shall participate in management through his right to vote. Not only may the tenant-owners remove the manager, they nuay pass resolutions directing the manager to carry out their will. ${ }^{324}$

Because of the problems pecuhar to community apartment developments some administrative officials feel that the Real Estate Commissioner is presently illequipped to protect the interests of purchasers. ${ }^{325}$ Under the Real Estate Law the commissioner may not only compel "full disclosure," he may prohibit any sale of a unit which "would constitute misrepresentation to or deceit or fraud of the purchasers ...." ${ }^{326}$ Although this would be adequate to prevent many of the abuses that have occurred in community apartment promotions, ${ }^{327}$ further controls would

322 See note 321 supra.

323 Some administrative officials assume that the tenant-owner is precluded from participation in the upkeep of the building. This assumption is questionable. Although the tenantowners do delegate this job to a manager, the writers have not encountered any instance in which the manager has the exclusive authority to keep the building in good repair. The tenantowner as a cotenant would have a right to fix anything that went wrong. Furthermore, he should have the right to contribution from the other tenant-owners for any necessary expenditures since they have agreed to assist in keeping the building in good repair. See Higgins v. Eva, 204 Cal. 231, 267 Pac. 1081 (1928) ; Robinson v. Bledsoe, 23 Cal. App. 687, 139 Pac. 245 (1914).

Also it should be noted that the position of the tenant-owner as an occupant of the property in which be has invested is far different from that of the investor many miles from the site of his property or the investor who can only rely on the conduct of others to increase his property's value. See, e.g., cases cited in note 319 supra.

324 See $\S \S 4,6$ of Declaration of Covenants, Conditions, and Restrictions, Palo Alto Estates. This is quite different from the position of a corporate shareholder who technically has only the right to remove directors from the board and who has no direct control over the management policy.

325 Interview With California Deputy Attorney General B. L. Hoisington, San Francisco, Feb. 28, 1962.

326 Cal. Bus. \& Prof. Code $\$ 11019$ provides:

An order prohibiting the sale ... of the property in this state may be issued by the commissioner if the examination of the project shows that the sale ... would constitute misrepresentations to or deceit or fraud of the purchasers ... of lots or parcels in the subdivision.

327 In Hawain, for example, the authors were informed that promoters would advertise "parking available." After purchasing a unit, however, the tenant would often find that parking was available, but only for an exorbitant monthly fee payable to the promoter. Interview With Members of the Hawaiian Bar, Honolulu, Dec. 1961. 
seem advisable. Since the heart of a successful condominium is a well drafted declaration of covenants some agency should be vested with the power to apply a "fair, just, and equitable" standard to those declarations.

Nevertheless, subjecting condominium to securities regulation is not a proper solution for several reasons, even if the tenant-owners' interests are within the definition of a security. First of all, it would be unnecessarily burdensome for condominiums to be regulated by both the real estate and corporation commissioners. Secondly, all sales of condommium units by agents would have to be made through a licensed stockbroker. ${ }^{328}$ Lastly, it would seem that the many tenancyin-common apartments sold in the last few years are also securities. ${ }^{329}$ If they are, any dissatisfied purchaser could void the sale and sue the seller for the price ${ }^{330}$ since they have been sold without a permit from the corporations commissioner. ${ }^{331}$

The appropriate solution would seem to be legislation subjecting condominiums to but one regulatory agency, equipped to adequately protect purchasers, and avoiding any umecessary admimistrative burdens on condominium developers.

\section{CONCLUSION}

Community apartments may lelp to solve the problem of providing homes in concentrated urban areas. They are designed to appeal to purchasers who want the satisfaction of home ownership, but who do not want the individual management responsibility that generally accompanies it. As has been pointed out, these are to some extent conflicting desires. Effective management depends on adequate control of the owners, which is achieved at the expense of some of the attributes of home ownership.

Two of the principal forms of community apartment ownership, stock cooperatives and condomimiuns, have been analysed and compared. Neither can be said to be the better form. Condominiums offer more ownership independence, and therefore less effective management, than do stock cooperatives. Therefore, condominiums are better for purchasers whose chief interest is in maximum independence from their neighbors. On the other hand, stock cooperatives are better for those who desire maximum control of and protection from their neighbors, and who are willing to submit theinselves to the same control and to undertake the concomitant interdependent financial responsibility.

Thus, each form of community apartment will satisfy different consumer demands. The choice is for each developer and consumer to make. It is hoped that this Comment will help them to make an informed decision.

Herbert J. Friedman

James $K$. Herbert

328 CAL. CORP. CODE $§ \S 25005,25700$.

320 T.I.C.'s, or tenancies-in-common, differ from condominiums only in the way the several interest is held-in a T.I.C. it is an irrevocable license to occupy as opposed to the fee simple interest in a condominium. For an excellent discussion of T.I.C.'s see BARBER, Co-op-The Deed Plan Comntunity Apartment Project, 36 CAL. S.B.J. 310 (1961).

830 These apartments have been sold under the assumption that they are not securities on the basis of an attorney general's opinion. 11 Ops. CAI. ATT'Y GEN. 81 (1948).

331 CAL. CoRp. CODE $\$ 26100$. For a discussion of the effect of this statute see Dahlquist, Regulation and Civil Liability Under the California Corporate Securities Act: III, 34 CALIF. L. REv. 543 (1946). 